\title{
PRELIMINARY FEASIBILITY STUDY OF HEATING AND COOLING ALTERNATIVES FOR NEBRASKA WESTERN COLLEGE, SCOTTSBLUFF, NEBRASKA
}

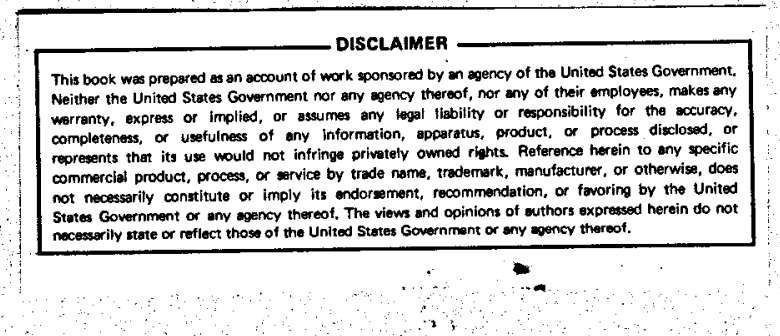

2. American Geothermal Energy Associates Omaha, Nebraska

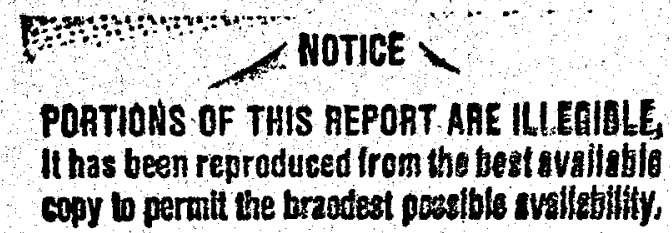

Prepared for EGEG Idaho, Inc. Under Subcontract No. K-7767 MN only and the U.S. Department of Energy Idaho Operations Office

Under DOE Contract No. DE-AC07-76ID01570 


\section{DISCLAIMER}

This report was prepared as an account of work sponsored by an agency of the United States Government. Neither the United States Government nor any agency Thereof, nor any of their employees, makes any warranty, express or implied, or assumes any legal liability or responsibility for the accuracy, completeness, or usefulness of any information, apparatus, product, or process disclosed, or represents that its use would not infringe privately owned rights. Reference herein to any specific commercial product, process, or service by trade name, trademark, manufacturer, or otherwise does not necessarily constitute or imply its endorsement, recommendation, or favoring by the United States Government or any agency thereof. The views and opinions of authors expressed herein do not necessarily state or reflect those of the United States Government or any agency thereof. 


\section{DISCLAIMER}

Portions of this document may be illegible in electronic image products. Images are produced from the best available original document. 



\section{PREFACE}

This report was prepared for EG\&G Idaho by American Geothermal Energy Associates on Subcontract No. K-7767 under the Department of

Energy's Outreach Program. It is now being reissued as an EG\&G formal report in order to make it available to others who may be interested in this geothermal application. 
. 


\section{FOREWORD}

The Geothermal Technical Assistance Program was developed under the premise that the majority of groups or individuals with available geothermal resources do not have the experience or manpower necessary to do a preliminary engineering and economic feasibility evaluation for geothermal energy projects. In order to disseminate technical information and to facilitate expanded use of geothermal energy resources, assistance was provided through FY-1981 in a consulting format on a first-come, staff-andfunds-available basis. Technical assistance can relate to conceptualization; engineering; economics; water chemistry implications for environmental, disposal, and material selection considerations; and planning and development strategies. This report is one of a series adapted from consultation provided to requesters either through in-house efforts or through limited efforts subcontracted to local engineering firms. The Geothermal Technical Assistance (GTA) Reports in this series, which are listed below, will be available for purchase early in 1982 by those with interest in specific geothermal applications from the U.S. National Technical Information Service:

U.S. Department of Commerce, National Technical Information Service, 5285 Port Royal Road, Springfield, VA 22161, (703) $557-4650$

GTA

Report Number

$\mathbf{i}$

1.

2.

3.

4.

5.

6.

7.

8.

9.
EG\&G

Report Number

*EGG-GTH-5512

•EGG-GTH-5521

*EGG-GTH-5573

EEGG-GTH-5574

*EGG-GTH-5575

*EGG-GTH-5599

EGG-GTH-5617

*EGG-2137

*EGG-2138
Title

Aquaculture Facility Potential at Boulder Hot Springs, Boulder, Montana

Preliminary Geothermal Disposal Considerations, State Health Laboratory, Boise, Idaho

Geothermal Conversion at Veterans Hospital, Boise, Idaho

Geothermal Applications for Highway Rest Areas

Geothermal Applications for a Tannery

Preliminary Conceptual Design for Geothermal Space Heating Conversion of School District 50 Joint Facilities at Pagosa Springs, Colorado

Selected Geothermal Technical Assistance Efforts (comprising short descriptions of ten space heating projects, five district heating projects, and three heat exchanger projects)

Geothermal Source Potential and Utilization for Methane Generation and Alcohol Production (subcontractor report)

Geothermal Source Potential and Utilization for Alcohol Production (subcontractor report) 
GTA

Report Number

10.

11.

12.

13.

14.

15.

16.

17.

18.

19.

20.

21.

22.

23.

24.

25.

26.
EG\&G

Report Number

*EGG-2139

*EGG-2144

EGO-2145

EGG-2146

EOG-2147

EGG-2148

EGG-2149

EGG-2150

EGG-2151

EGG-2152

EGG-2153

EGG-2154

EGG-2155

EGG-2156

•EGG-GTH-5739

EGG-GTH-5740

EEGG-GTH-5741
Title

Potential Geothermal Energy Applications for Idaho Elks Rehabilitation Hospital (subcontractor report)

Technical Assistance Repart on a Geothermal Heating Utility for Lemmon, South Dakota (subcontractor report)

Economic Analysis for Utilization of Geothermal Energy by North Dakota Concrete Products Company (subcontractor report)

Geothermal Feasibility Analysis II for Polo School District No. 29-2, South Dakola (subcontractor report)

Preliminary Feasibility study of Heating and Cooling Alternatives for Nebraska Western College, Scottsbluff, Nebraska (subcontractor report)

Inventory of Thermal Springs and Wells Within a OneMile Radius of Yucca Lodge, Truth or Consequences, New Mexico (subcontractor report)

Space Heating for Spa Facilities at Ojo Caliente, New Mexico (subcontractor report)

Space Heating for Office Building at Glenwood Springs, Colorado (subcontractor report)

District Heating for Subdivision in Dickinson, North Dakota (subcontractor report)

Space Heating for Subdivision in Truth or Consequences, New Mexico (subcontractor report)

Space Heating for Veterans Administration Medical Center, Marlin, Texas (subcontractor report)

District Heating for Subdivision in Castle Rock, Colorado (subcontractor report)

Space Heating for Twin Lakes School Near Gallup, New Mexico (subcontractor report)

Pumping Tests of Well Campbell Et Al. No. 2, Gila Hot Springs, Grant County, New Mexico (subcontractor report)

Geothermal Deicing of Bridge Structures

Assessment of a Geothermal Application at Tucson, Arizona

Heat Pump Systems for Spring Creek, Montana 


\begin{tabular}{|c|c|c|}
\hline $\begin{array}{l}\text { GTA } \\
\text { Report Number } \\
\end{array}$ & $\begin{array}{l}\text { EG\&G } \\
\text { Report Number }\end{array}$ & Title \\
\hline 27. & EGG-GTH-5779 & Pipe Selection Guide \\
\hline 28. & EGG-GTH-5804 & $\begin{array}{l}\text { An Overview of Engineering and Agricultural Design } \\
\text { Considerations of the Raft River Soil-Warming and } \\
\text { Heat-Dissipation Experiment }\end{array}$ \\
\hline 29. & EGG-GTH-5812 & $\begin{array}{l}\text { Design of the Glenwood Springs Downhole Heat } \\
\text { Exchanger }\end{array}$ \\
\hline
\end{tabular}

Published as of 3/15/82. 
P 
1

\section{PRELIMINARY FEASIBILITY STUDY OF HEATING AND COOLING AITERNATIVES}

For

Nebraska Western College

Scottsbluff, Nebraska

by

\section{American Geothermal Energy Associates \\ Omaha, Nebraska}

october, 1981

Subcontract No. $\mathrm{K}-7767$ 
Page

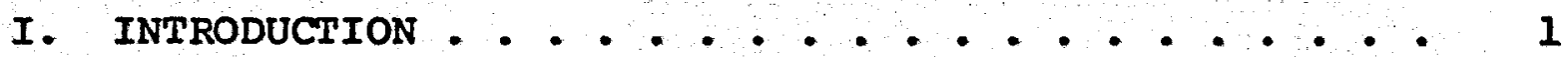

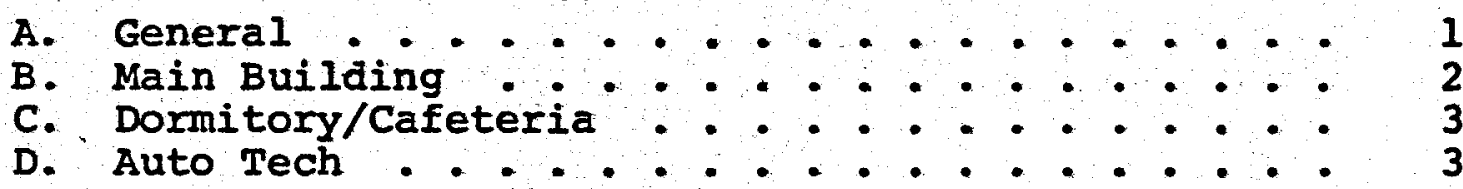

II. CURRENT HEATING/COOLING ECONOMICS . . . . . . . . 4

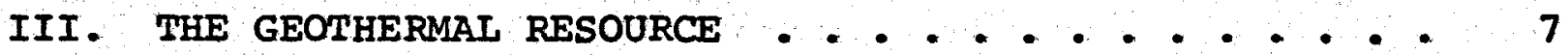

A. General Geology near Scottsbluff . . . . . . 7

B. Specific Geology near Proposed Site . . . . . 8

C. Groundwater Potential in Dakota Group . . . . 9

D. The Geothermal Heat . . . . . . . . . 16

IV. GEOTHERMAL RESOURCE UTIIIZATION . . . . . . . . 17

A. Development of Wells . . . . . . . 17

1. Delivery Well .............. 17

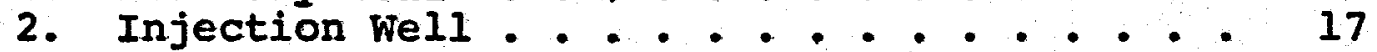

B. Retrofitting for Geothermal Heating . . . . . 19

1. General . . . . . . . . . . . 19

2. Building Complex Load Determination . . . 21

3. Geothermal Resource Sizing . . . . . . 25

4. Utilization of the Geothermal Resource in 2

5. Geothermal Resource--Mechanical:System

Interface .................. 34

6. Retrofit Measures anđ Costs . . . . . 36

7. Cooling Assessment ............ 41

V. COST-BENEFIT ANALYSIS FOR GEOTHERMAL RESOURCE _ _ — 42

VI. ENERGY ALTERNATIVES EXCLUSIVE OF GEOTHERMAL _ _ . 44

A. Energy/Management Conservation . . . . . . 44

B. Cooling with Unconfined Groundwater . . . . . 44

C. Heating/Cooling with Groundwater Heat Pumps . . 45

VII. CONCLUSIONS . . . . . . . . . . . . . . . 48

VIII. APPENDICES - . . . . . . . . . . . . - . 50

A. Questions from Nebraska Western College . . . 50

B. Geothermal Calculations . . . . . . . 52 


\section{TABLE OF CONTENTS (CONTINUED)}

Page

1. Pump Sizing
2. Costs
C. Climatological Data

IX. REFERENCES ................... . . . 60

A. Geology References ............ 60

B. Retrofitting References ........... 61 


\section{Introduction}

\section{A. General}

The existence of a recently-recognized, low-temperature, geothermal resource under central and western Nebraska represents a potential alternate energy source. This report addresses the feasibility of using that resource for space heating and cooling at Nebraska Western College, Scottsbluff, Nebraska, as an alternative to that facility's current, natural-gas fired, heating and cooling system.

In this investigation of feasibility, this study addresses a) the geological (hydrological) aspects of such a project, b) the retrofitting requirements for modifying the existing heating plants to accommodate the geothermal resource, c) the possible use of shallow, unconfined groundwater with heat pumps as another energy alternative, and d) the economic costs and benefits of both deep and shallow-water hydrothermal application. Nebraska Western College is a facility located on the northeast edge of scottsbluff, Nebraska. It is in the business of providing two years of post-secondary education to students of the region and is fully operational for nearly twelve months of the year. Intersession periods, measured in weeks, are excepted. Nebraska Western has become a community focus for certain sporting and cultural events and the auditorium is heavily 
utilized by various community organizations on a rental basis. The facility consists of three buildings, each having been designed and constructed independently as the college grew and finances became available.

B. Main Building

The Main Building is the largest structure and is about 20 years old. It is of somewhat modular design, consisting of roughly three interconnected pods. One pod contains central offices and library; another contains classroom and offices for faculty; the third is a two-story structure that houses a large circular gymnasium and several classroom offices.

The Main Building is 170,000 square feet and is heated and cooled by its own plant. Heating/cooling fancoils distribute conditioned air and are generally placed above the air conditioned space. In the $1 \frac{1}{2}$ story pods the fancoils are placed above suspended ceilings; these pods also contain fresh-air exchangers in their roofs. In the single-story pods fancoils are exposed and are located directly below the ceiling.

Hot/cold water is supplied to distribution fancoils from the Main Building heating/cooling plant which consists of two gas-fired boilers and a compressor-type water chiller.

The Main Building is constructed of $8^{\prime \prime}$ concrete block which is faced with brick. Interior walls are plastered. The roofs consist of five layers of built-up felt and tar, and are 
gravel-coated. Two inches of fiberglass insulation underlays the roof covering. Ceilings are of concrete which is sprayed onto iron lath. In most areas only a few inches (usually two or less) of space separates the ceiling lath and the roof underlayment. Windows are single pane and permanently sealed.

C. Dormitory/Cafeteria

The Dormitory/Cafeteria is a 3 -story structure, including basement, and consists of 35,000 square feet. It is structuraliy similar to the Main Building. Insulating properties are the same. Air is distributed and conditioned by hot/cold water fancoil units. Hot and cold water for the coil units is provided by two gasfired Servel heat absorption air conditions. (Interestingly these units amount to more than 258 of the heating/air maintenance time for the entire campus, according to the Plant supervisor.)

\section{Auto Tech}

The Auto-tech building is a single-level structure that is approximately one and one-half stories tall to accommodate large trucks and heavy implements. This structure is 25,000 square feet. The air is heated and cooled by individual, selfcontained, ceiling-hung units. At this time only three cooling units are operative, having been rendered inoperative by lightning strikes. However, during the sumer and often in winter, several of the garage doors are partially, if not fully open, to 
exhaust engine fumes and to increase fresh air circulation. The building has a flat felt and tar, graveled roof. Two inches of fiberglass insulation currently exist just below the roof.

\section{Current Heating/Cooling Economics.}

The air-conditioning facilities of the three

buildings are separate, are metered separately and may be analyzed individually as to their economics; for the purposes of this analysis, the data for the Main Building and Dormitory are used to create an average-annual-energy picture for Nebraska Western College.

A review of monthly-meteorological data for Scottsbluff since 1975 reveals that the period September 1979 through August 1980 most closely typifies a "normal" heating/cooling year, based on 65 year averages for scottsbluff. The dots adjacent to the degree days for $1979-80$ in Figure 1 represent the monthly 65 year means. Figure 1 also plots the actual monthly naturalgas consumption (in cubic feet) and electricity consumption (kwhr) from January 1978 through April 1981 for the entire campus of Nebraska Western.

A quick review of Figure 1 reveals some interesting and useful trends. Minima for gas and electricity consumption occur in June and also again in the Fall. The heating and air-conditioning plants are generally not operative during June and the students are absent from campus for part of that month. 
1
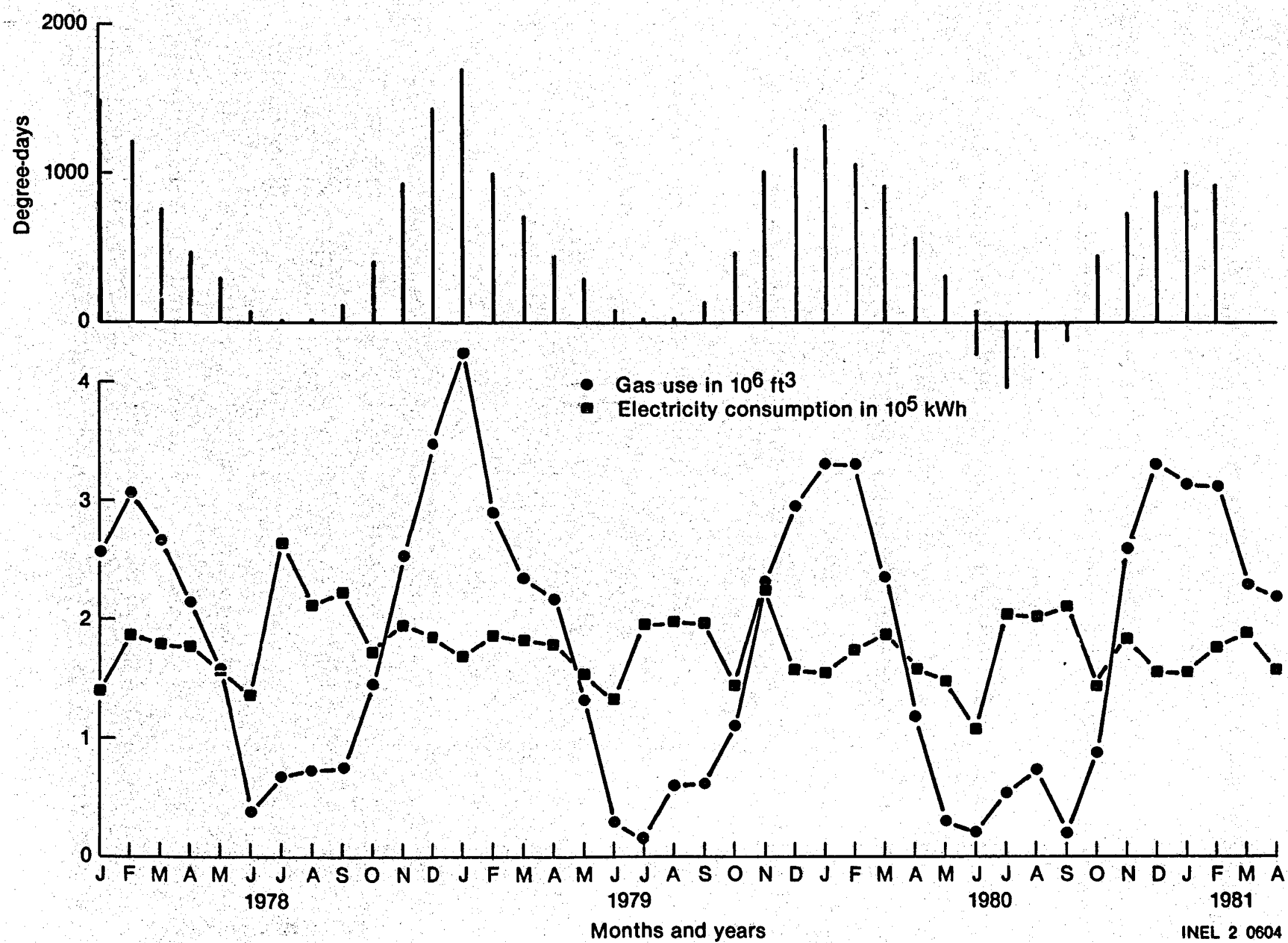

Figure 1. Consumption patterns. 
Circulating fans, however, are operative and the building is conditioned with outside make-up air. The June lows in naturalgas consumption can be used to establish a baseline for minimummaintenance consumption. This baseline or minimum-maintenance consumption amounts to about $0.15 \times 10^{6} \mathrm{cubic}$ feet/month.

Note also a sudden increase in gas consumption in July and August which peaks at $0.75 \times 10^{6}$ cubic feet/month. This increase reflects mostly consumption which may be attributed to the gas-fired absorption air conditioner in the dormitory. A very rough seasonal energy consumption for that piece of equipment in the cooling mode is $0.9 \times 10^{6} \mathrm{ft}^{3}$ of gas.

Similarly, a baseline for minimum electricity consumption is $1.3-1.5 \times 10^{5} \mathrm{kWhr} /$ month, based on June lows. Roughly $3 \times 10^{5} \mathrm{kWhr}$ are used annually for air conditioning. Thus for the purposes of creating a typical portrayal of Nebraska Western's energy consumption using the existing system the following assumptions are made:

1) That the 1979-80 heating/cooling season is "average" for estimating contemporary energy consumption.

2) That the gas/electricity consumption for heating/cooling in 1979-80 reflects those heating/cooling degree days.

3) Contemporary prices for natural gas and electricity are based on Spring, 19:81, Scottsbluff prices at the rate of $\$ 0.262$ per CCF of gas and $\$ 0.0336$ per $\mathrm{kWhr}$. 
4) That $0.9 \times 10^{6} \mathrm{ft}^{3}$ of gas and $3 \times 10^{5} \mathrm{kWhr}$ of electricity are used for summer air conditioning.

\section{Annual Energy Demands}

Heating

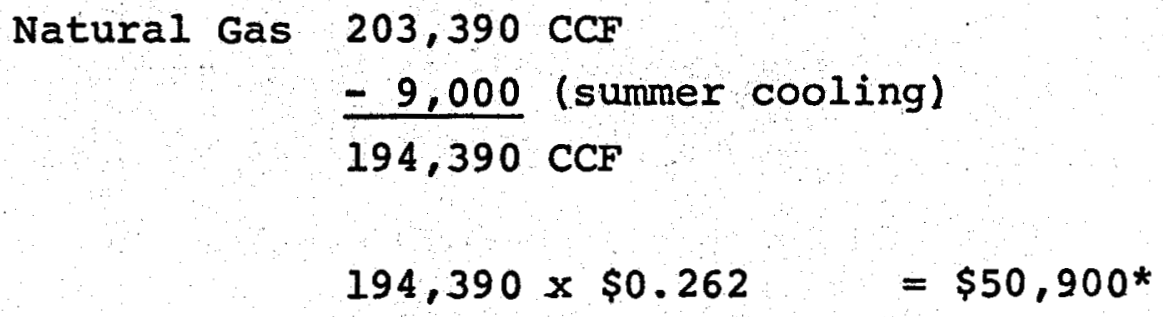

cooling

Natural Gas $\quad 9,000 \mathrm{CCF}$

$$
9,000 \times \$ 0.262=\$ 2,400
$$

Electricity $\quad 3 \times 10^{5} \mathrm{kWhr}$

$$
3 \times 10^{5} \times \$ 0.0336=\$ 10,000
$$

Total cooling Costs $=\$ 12,400$

TOTAL HEATING AND COOLING $=\$ 63,000 * *$

Total Electricity Consumption: $1,747,200 \mathrm{kWhr}$
(exclusive of cooling) $\quad \mathrm{x} \$ 0.0336=\$ 59,000 * *$

TOTAL ANNUAL ENERGY COSTS (aI1 forms) \$122,000** 
III. The Geothermal Resource

A. General Geology near Scottsbluff

The scottsbluff area is underlain by a few tens to hundreds of feet of alluvium overlying several hundred feet of porous and permeable flat-lying Tertiary rocks that increase in thickness by an order of magnitude from north to south. The water table in this upper section is about 60 feet below the proposed site. The Tertiary rocks in turn overlie the cretaceous section. Minor faulting may occur but offsets are not large. The stratigraphy of the potential deep pay horizons of low temperature waters in western Nebraska involves part of the lower Cretaceous section and possibly the upper Jurassic. The Cretaceous section includes, in descending order, the Montana Group (Pierre Shale and minor sandstones), the Colorado Group (Smokey Hill Chalk, Fort Hays Limestone, Carlile Shale, Green Horn Limestone, Graneros or Belle Fourche Shalel, and the Dakota Group (Omadi sandstones, Skull Creek Shale, and Fall RiverLakota Sandstones). Below this occur various sandstones in the Morrison Formation of late Jurassic age.

The various sandstones of the Dakota Group, and possibly those of the Morrison Formation, are the units of interest. Considerable relevant detail is known about the Dakota sandstones because they are also oil and gas producers in the area around scottsbluff. Thus the omadi sandstones are divided into various 
subunits, the most important of which are "D" sand, "G" sand, and " $J$ " sand. Because these sandstones were originally deposited as offshore bar, beach, and stream channels, they are lenticular, partially discontinuous laterally and vertically, shoestring in nature, and interbedded with impermeable shales. The sandstones are considered, however, to be interconnected. Total thickness of the omadi is therefore variable but is commoniy on the order of several hundred feet thick. Individual sandstone units range from stringers to slightly over 100 feet thick. These units are separated from the underlying Fall River and Lakota sandstones by $100-200$ feet of skull creek Shale. The Fall River may not be more than 50 feet thick. The Lakota may be about 250 feet thick. These units pass downward into about 150 feet of interbedded sandstones and shales of the Morrison Formation below. We are therefore considering the total potential pay horizon at about 500 feet thick.

\section{B. Specific Geology near Proposed Sites}

The nearest boreholes in the Dakota Group near Scottsbluff are all a few miles from town and, because of the known lenticularity of the rocks, can only give general ideas about locations of a specific sandstone reservoir. Cretaceous specialist, Hal Degraw, of Nebraska Conservation and Survey Division has produced a map of the " $D$ " sand which shows it to be thin or missing directly beneath the site but thick a few miles away to 
the west. Nevertheless he points out that his map is only a subjective probability based on very few wells, and that the " $D$ " sand could well occur there. Because this sand is the main hydrocarbon producer in the area and has thus far proved dry or absent near scottsbluff, there are no deeper holes nearby. Therefore we know even less about the " $G$ " and " $J$ " sands, or indeed, about many of the other sandstones on down beneath. Nevertheless deeper wells tens of miles away show a profusion of : these sanastones so we can assume a high probability of their occurrence below the scottsbluff site. It would be very unusual indeed if at least one or more of these major sands aid not occur there. Also the probability of reaching a successful pay horizon increases far more with slightly deeper penetration into the thicker and continuous Fall River-Lakota Sandstones. Finally the Morrison sandstones will further add to the confidence of achieving enough potential pay horizon, especially considering that unlike oil drilling these resource sandstones are cumulative; the more arilled through, the greater the increase of it available resource.

c. Groundwater potential in Dakota Group

Information specific to deep artesian groundwater in the sandstones of the Dakota Group is extremely difficult to obtain because of proprietary interests on the part of oil companies. Nevertheless we have obtained some. reliable data about general 
characteristics elsewhere and with this as a basis for informal speculation, we can probably come fairly close to an accurate predictive picture.

The Dakota Group is famous as an artesian aquifer across much of the High Plains. This aquifer has been long assumed to have a "classic" freshwater recharge zone around the nearby mountains, with a steady flow down into the hot Denver Basin and up into western Nebraska. This idea has long been somewhat disputed in matters of detail by others as cited by Schoon (1971). In these alternate schemes, original or connate water from marine, brackish, and freshwater depositional environments is trapped in the sediments at the time of burial and subsequently pressurized by the compaction of the sediments against the incompressibility of the water. Evidence for this idea is that water quality in the Dakota is highly variable in both south Dakota and western Nebraska, and zones of sodium chloride, sodium sulfate, calcium sulfate, iron compounds and other materials dissolved in the water are common. These dissolved solids are thought by some to be original formation water but there is also evidence of upward migration of water containing various dissolved components from other more deeply buried rocks. In many cases the lenticularity of the sandstone units may isolate these zones of low water quality but where enough permeability exists the rocks can also be flushed clean. Thus to summarize the three ideas about artesian flow in the Dakota, there is plenty 
of modern evidence to support, the old ideas of more or less lateral hydraulic migration from recharge zones, of more or less vertical migration from lower zones, and of original connate water trapped after deposition. The significance of this to the Scottsbluff site, or indeed of any other in western Nebraska is that considerable variability in water quality and quantity must be expected. Oil geologist Jack Fische (verbal communication, June, 1981) mentioned that 7500 ppm chlorides and $15000 \mathrm{ppm}$ total dissolved solids would be typical of wells near scottsbluff. In comparison sea water salinity is $35000 \mathrm{ppm}$. In addition, heavy pumping of the Dakota in parts of Nebraska has been observed to reduce quality (Christiansen Brothers Well Drilling, verbal communication, 1981). Specific information is limited about actual water conditions in the relevant units near scottsbluff, however. Successful oil wells drilled in western Nebraska in the Dakota Group were commonly developed with hydrofracturing techniques in order to increase flow of high viscosity and low pressure hydrocarbons into the wells. A common technique has been to reinject formation water in order to facilitate secondary recovery of hydrocarbons. Because the hydrocarbons in this area have tended to migrate upward, much of the oil and gas have concentrated in the uppermost Omadi sandstones. Proportionately less is therefore known about the deeper formations because drilling has not penetrated there. As a result, information about water gleaned from rather close-mouthed petroleum 
geologists and engineers in western Nebraska tends to err toward the conservative. Furthermore development of geothermal waters from hydrocarbon-bearing formations is perceived by some oil people as a potential hazard to their water-drive oil recovery techniques. This would certainly be true with heavy use of the geothermal resource over much of western Nebraska but is unlikeIy to affect our local first efforts. In addition we believe that deeper drilling will probably be necessary anyway to the lower sandstones, which are of little interest to the petroleum people, but which may contain sufficient hot water. Also the development of successful geothermal production in western Nebras$\mathrm{ka}$ is quite different than petroleum because unlike hydrocarbon pools in small stratigraphic highs, the water will extend to some depth in multiply-stacked pay zones. Thus we can ensure sufficient water merely by penetrating a number of those layercake sandstone units. This is especially significant in ensuring a long well life and will also provide somewhat greater heat with the increased depth.

Permeability in the Dakota ranges up to 1 darcy $(1.062$ $x 10^{-11} \mathrm{ft}^{2}$ ) but is probably going to average $200-250 \mathrm{mille}-$ darcies at the scottsbluff site. This is a coefficient of permeability of about $5-20 \mathrm{gal} / \mathrm{day} / \mathrm{ft}^{2}$. According to Todd $(1960$, p. 53) these values range right around the cutoff point between the good aquifers and the best of the poor aquifers in unconsolidated sediments. The consolidated bedrock of the Dakota is therefore a good aquifer. 
Because of the probable limited nature of the " $D$ " sand under Scottsbluff, Chain Oil Company head, Jack Chain, reckons pumping from that unit alone could only be about $60 \mathrm{gals} / \mathrm{min}$ and the well life would be shortened by rapid drawdown. Aside from the aforementioned problem of perceived conflict between hydrocarbon and geothermal production, penetration to slightly greater depths and other sands should achieve pumping rates of 150 gals/min.

The exact configuration of the potentiometric surface, or height to which the artesian water of the Dakota Group will rise is problematic. Based on calculations of drill-stem tests on oil exploration wells, the potentiometric surface for water in the upper Dakota sandstones at the Scottsbluff site is about 1850 feet above sea level (H. DeGraw, 1969). With the surface elevation of about 3960 feet, this produces a pressure surface at 2110 feet below the ground surface. The top of the Dakota is at about 4700 feet below ground (Reed, 1952; Carlson and Reed, 1961; Volk, 1972) so total water rise in the well would be about 2590 feet. The problem with these data, however, is that DeGraw's pressure surface is not static but is based upon observations for several decades and therefore includes drawdown, from oil and gas pumping. More recent (1981) unpublished data by Jorgenson show the potentiometric surface near scottsbluff to be about 2400 feet a.s.l. so that the pressure surface is actually only about 1560 feet below the ground and the total water rise in the well would be about 3140 feet. The difference between the two 
calculated figures of water rise is therefore $550 \mathrm{ft}$. It is interesting to note that this figure is almost exactly the relief, or local difference between highs and lows on DeGraw's potentiometric map and therefore probably represents the approximate cumulative arawdown from pumping oil and gas in the area over the last several decades. The replication of these two figures probably represents the best possible calculation for pumping drawdown without the usual pumping tests and other observation wells to determine the shape and dimension of the cone of depression. In the negative scenario, if we use figures from DeGraw's map, we arbitrarily site the pump half way between the top of the formation and the pressure surface. The pump would then be located at about 1295 feet (half of 2890 feet) above the top of the Dakota, which means that the location of the pump should be about 3500 feet below ground surface with a total maximum well depth of about 5200 feet. Using the figures derived from the Jorgenson data, combined with that of DeGraw, however, means that a drawdown of 550 feet is more likely. Thus the pump would be sited at about 2600 feet above the Dakota, or at about 2110 feet below ground.

In summary, the maximum height to lift water would be about $3500 \mathrm{ft}$. and the minimum about $2100 \mathrm{ft}$. This 1400 foot difference produces some uncertainty in the financial analysis, which is to be expected given the "wildcat" nature of such geologic exploration. Therefore we will use the most pessimistic estimate. 
The probable life of the well is also difficult to . estimate because of the limited local information available. DeGraw's map does show the effects of several decades of pumping and the drawdown is not extreme.

Several things may negatively affect geothermal water production based on conditions that are not possible to predict accurately at the present time. The first problem is that in spite of the reasonable permeabilities and flow rates which we expect, drawdown of a limited reservoir may occur such that insufficient water is available over time. Again, in light of the above and with care and penetration of sufficient sandstone to provide an oversupply of water in these first attempts at geothermal production in western Nebraska, we think that a long well life of at least 20 years is possible but we can present no calculations to prove this. A well life of 20 years and beyond is very likely, however, because such waters have been pumped for decades in the oil fields there, and we have sited the pump very deep in our pessimistic scenario, which will tend to offset such effects of a deep cone of depression. A second problem is degradation of the aquifer or well installation through well site cementation or through scale development on casing and pump. This is a difficult problem and depends upon the original water quality. Redevelopment of oil and water wells with these problems is common and can involve simple solutions like inexpensive acid flushing or expensive redevelopment and recasing. While we 
do not anticipate such problems to be severe if the well is adequately developed in the first place, some attention must be : paid to these potentials for problems, just as in most geological engineering endeavors. In any case there are many remedial techniques which can be brought to bear at a later date.

D. The Geothermal Heat

The new work on geothermal resources in western Nebraska (Gosnold and Eversoll, in press; Gosnold, Eversoll, and Carlson, oral communication, June 1981) includes equilibrium temperature measurements in 7 deep oil wells in the Dakota Group and 18 related heat flow holes from which temperatures at depth were projected. Their work clearly shows a temperature regime beneath scottsbluff in excess of $90^{\circ} \mathrm{C}\left(194^{\circ} \mathrm{F}\right)$. These high temperatures are primarily due to normal conductive heat flux and low-thermal conductivity sediments.

This heat is thought by them to derive from water flowing updip out of the Denver Basin, but they note that DeGraw's (1969) piezometric map does not show a hydraulic gradient reflecting this probability. This is probably because the updip flow is in the basal sandstones, which were not mapped for pressure. In any case it is clear from their projected data that water close to the boiling point should exist near scottsbluff and should therefore be available for heating as is proposed. 
IV. Geothermal Resource Utilization

A. Development of Wells

1. Delivery Well. The projected well depth is to be about 5200 feet near the bottom of the Dakota Group, unless sufficient water is found at lesser depths. According to Bouwer (1978, p. 157) wells which pump between $400-1000 \mathrm{~m}^{3} /$ day need a well diameter of $20 \mathrm{~cm}$. The proposed pumping at scottsbluff of $150 \mathrm{gal} / \mathrm{min}$ corresponds to $780 \mathrm{~m}^{3} / \mathrm{day}$ and such flow rates thus are normally handled by an 8 inch casing. Overdesign for scale buildup could necessitate 10 inch casing.

Well drilling would be standard oil well technology without all the elaborate and expensive blowout prevention technology. The well, wire line electric log test, and pumping test would be about $\$ 65,000$ at prevailing prices in scottsbluff. Casing at $\$ 15.00 /$ foot to 5200 feet and finishing would run about $\$ 80,000$. The delivery pump will cost about $\$ 46,400$.

2. Injection Well. The approximate elevation of the Scottsbluff site is 3960 feet and the water table is only about 60 feet below ground. The unconfined water table aquifer by state law must be protected from possible degradation caused by dissolved solids or excess heat in the geothermal waters brought to the surface. Thus some sort of disposal system is necessary unless in the unusual event that the Dakota aquifer produces water of sufficient quality to augment surface supplies. 
similarly, although there is no state law to this effect, we must avoid degradation of the Dakota geothermal aquifer, both in possible dewatering or in cooling. A reinjection well must therefore be considered.

Water law in Nebraska is in a considerable state of flux at the moment because of various problems with near surface supplies in different parts of the state. Specifics about reinjection wells are thus not yet completely clear, although draft Iegislation is being considered. According to these new proposals, geothermal injection wells are class $v$, which also includes septic systems and aquifer recharge wells. On the other hand the probable chloride content and depth might make the proposed well class I. In any case, reinjection of the brackish Dakota waters is common in the oil business in western Nebraska. These regulations are designed to ensure that there is no violation of primary drinking water standards either in the source or the sink aquifers. The Dakota is an exempted aguifer which means that it is not itself a source of arinking water, but no poor quality water from it could be injected into any other arinking-water aquifer. Thus permits for injection are required for these wells and they are monitored at various times in the future. This ensures the protection of freshwater aquifers. Because geothermal aquifers are a new consideration little attention has yet been paid to their degradation. This oversight would soon be corrected if the resource proves 
economically competitive with other energy sources. Thus attention must be paid to potential drawdown of the Dakota Sandstones if no reinjection into the pay horizon occurs. Nevertheless the reinjection must be a sufficient distance from the producing well in order not to produce adverse communication between wells. This distance is some function of thermal conductivity and site-specific permeability of the units penetrated. Because of the large number of uncertainties with this, there seems little point in calculating this at the present time. Thus it is necessary to bore the injection well to about 5200 feet and case it to the top of the Dakota at about 4700 feet. Boring costs would be about $\$ 65,000$ and casing and finishing about $\$ 40,000$. The reinjection pump would cost about $\$ 2,000$.

\section{B. Retrofitting for Geothermal Heating}

1. General. The report that follows is a cursory examination of retrofitting feasibility. By its very nature, the scope of the report is intended to provide only a superficial determination of feasibility. The report speaks in general about adaptation of the existing mechanical-system components and control strategy to yield a plausible replacement system. This study was performed with somewhat limited information concerning the existing physical plant at the college complex. The available mechanical information was linited to the following: 
a) an equipment list describing the major components of mechanical equipment in the Administration/Classroom Builaing, the Dormitory and the Garage/Motor Pool Building:

b) an energy-consumption record showing natural-gas and electricity usage and actual heating degree days from January 1978 to February 1981 for the entire college complex.

Some information was not available for this study. However it is felt that the absence of such data should not significantly affect a retrofitting estimate. Data that were absent included:

a) schematics of the mechanical systems;

b) building floor plans showing mechanical equipment location and layout;

c) heating and cooling load calculations for the existing buildings;

d) hot-water loads and related fuel use. Because of the limits on available information, several assumptions had to be made in this examination. These assumptions are noted in the course of the report and appropriate references are provided so that those reviewing this document may judge its validity for themselves. English units are used throughout this report because English units conform to standard HVAC practice. 
2. Building Complex Load Determination: As a starting point, the energy-consumption history of the college complex was used to estimate the energy consumed by the complex on a degreeday basis. Data were available for half of the 1977-78 heating season, all of the 1978-1979 and the 1979-1980, and most of the 1980-1981 season. The data of consumption to the Main Building and Dorms are lumped with the Auto Tech. The Well Building is separate.

A "Modified Degree Day Procedure" is recommended by ASHRAE for use in predicting fuel requirements for builaings. 1 Since actual energy-use data were available, this procedure was worked backwards to calculate a value for the heat loss. This heat loss is then used to derive an average heat loss per degree day by the complex. The general relation for fuel calculations using the Modified degree day Procedure is:

$$
F=\frac{24(D D)(\dot{Q})}{n\left(t_{i}-t_{0}\right) H} C_{D} C_{F}
$$

where:

$F=$ the quantity of fuel required for the period desired $\left(\mathrm{ft} \mathrm{t}^{3}\right)$

$D D=$ the degree days for period desired $\left({ }^{\circ} \mathrm{F} \cdot\right.$ day $)$

$\dot{Q}=$ the total heat loss based on design conditions of $t_{i}$ and $t_{0}(B T U / h r)$

$n=$ the rated full load efficiency of the heating equipment

$\mathrm{H}=$ the heating value of the fuel $\left(1000 \mathrm{BTU} / \mathrm{ft}^{3}\right)$

1

See references-section IXB 
$C_{D}=$ an interim correction factor for degree days on $65^{\circ} \mathrm{F}$ $C_{F}=$ the interim partial load correction factor for fueled systems (accounts for decrease in efficiency for fueled furnaces under partial load)

Since actual fuel requirements (see Fig. 1) are already known, Equation 4.1 is solved for $\dot{Q}$. Natural gas consumption and actual degree days were totaled for each month in the heating season (Sept. to April) from January 1978 to February 1981. This yielded:

$F=51.6674 \times 10^{6} \mathrm{ft}^{3}$ for Main Builaing plus Dormitory $F=11.1940 \times 10^{6}$ for the Auto Tech. DD $=20,582$, which are the degree days over that usage period $n$, the rated full load efficiency of the heating equipment is 808 according to the manufacturer. However, since the equipment is approaching 20 years old, the following was chosen:

$$
n=.75
$$

$t_{i}=$ indoor design temperature $=.72^{\circ} \mathrm{F}$ (recommended for school. design in ASHRAE standard $90-80^{2}$,

$t_{0}=-3^{\circ} \mathrm{F}$ (ASHRAE $97 \frac{1}{2}$ winter DB Design Temperature for scottsbluff ${ }^{3}$ )

$\mathrm{H}=1000 \mathrm{BTU} / \mathrm{ft}^{3}$ (average heat content of natural gas)

$C_{D}=$ correction factor $=.69$ for $-3^{\circ} \mathrm{F}$ outdoor design temperature ${ }^{1}$

$C_{F}=$ correction factor for equipment oversizing. 
The heating equipment was selected using a $-20^{\circ} \mathrm{F}$ outside design temperature (reference Mechanical Equipment Schedule). This was compared with the recommended ASHRAE temperature of $-3^{\circ} \mathrm{F}$ relative to the $65^{\circ} \mathrm{F}$ degree day base to yield:

$$
\frac{65-(-20)}{65-(-3)}=1.25 \text { or } 258 \text { oversized, }
$$

therefore, $C_{F}=1.62$ (reference 1 ).

Before calculating the heat losses for the builaings, it. is useful to estimate the average hot-water consumption. Because there are 100 dormitory occupants and an active athletic program, it seems reasonable to expect 175 showers/day. Our assumption is that each shower takes 15 minutes and uses $120^{\circ} \mathrm{F}$ water at the rate of $2 \mathrm{gal} / \mathrm{min}$ and that the water was heated i: from $50^{\circ} \mathrm{F}$. For such usage one arrives at an average energy demand of $0.127 \times 10^{6} \mathrm{BTU} / \mathrm{hr}$. In adaition, the washrooms (used by 1500 students), kitchen, launäry, and janitorial services require hot water at a possible average of about $1 \mathrm{gal} / \mathrm{min}$, which yields an additional consumption of $0.035 \times 10^{6} \mathrm{BTU} / \mathrm{hr}$. The total energy demand for hot water is thus $0.162 \times 10^{6} \mathrm{BTU} / \mathrm{hr}$. Assuming 0.8 conversion, the natural-gas consumption is 2.05 $\times 10^{2} \mathrm{ft}^{3} / \mathrm{hr}$ or $3.9 \times 10^{6} \mathrm{ft}^{3}$ for the 27 month period in question. Because we will recommend heating the garage by installing floor heating, the garage consumption will be subtracted from the rest of the heat load. Assuming $80 \%$ of the Auto-Tech heating goes to keeping the garage warm we arrive at: 
$F_{G}=8.956 \times 10^{6} \mathrm{ft}^{3}$ for the garage.

For the remainder of the complex we get, after subtracting the hot-water load:

$$
\begin{aligned}
F_{M} & =(51.67+2.239-3.9) \times 10^{6} \mathrm{ft}^{3} \\
& =50 \times 10^{6} \mathrm{ft}^{3} .
\end{aligned}
$$

Using these values in Equation 4.1 results in:

$$
\begin{aligned}
& F=\frac{24(20582)(0.69)(1,62)}{0.75[72-(-3) ;(1000)} \dot{Q} \\
& \dot{Q}=.101873 \frac{\mathrm{BTU}}{\mathrm{hr} \mathrm{ft}^{3}} \mathrm{~F}
\end{aligned}
$$

Dividing by the temperature differential $\left(t_{i}-t_{0}\right)=75$ yields the local coefficients. For the garage-load coefficient (GLC)

$$
\begin{aligned}
\text { GLC } & =\frac{.101873}{75} \times 8.956 \times 10^{6} \frac{\mathrm{BTU}}{\mathrm{hr}{ }^{\circ} \mathrm{F}} \\
& =1.216 \times 10^{4} \frac{\mathrm{BTU}}{\mathrm{hr}}{ }^{\circ} \mathrm{F}
\end{aligned}
$$

and the main-load coefficient (MLC)

$$
\begin{aligned}
\mathrm{MLC} & =\frac{0.101873}{75} \times 50 \times 10^{6} \frac{\mathrm{BTU}}{\mathrm{hr}^{\circ} \mathrm{F}} \\
& =6.79 \times 10^{4} \frac{\mathrm{BTU}}{\mathrm{hr}}
\end{aligned}
$$

Two observations are in order here. First, the proce-

dure used above yields load coefficients ( $L C^{\prime} s$ ) developed from data averaged over three years. If this same procedure were applied using data for a single heating season, deviations of $\pm 10 \%$ would be experienced. Secondly, in calculating the energy requirements for heating, the internal gain from electrical-energy usage is included in net fuel consumption. From figure 1 it may be seen 
that electrical energy usage averages approximately 208 of the energy used as natural gas in mid-winter. For the purposes of this report, that electrical-energy usage will be treated as an internal gain and not included in the geothermal-load displacement. It is assumed that the electrical-energy usage, solar gain (if any) and internal gains from the builaing's occupants will provide sufficient energy so that for ambient temperatures of $65^{\circ} \mathrm{F}$ and above no theating will be required.

3. Geothermal Resource sizing. In sizing the geothernal resource, a balance must be struck to result in a system that is sufficiently large to supply a significant amount of energy on a yearly basis and yet not be so large that the system's peakoutput capacity is only marginally utilized throughout the year. A guiding principle throughout this evaluation was to have the existing gas-fired heating system available as backup for any geothermal system. This arrangement permits sizing of the geothermal resource without having to supply peak-load demand. Such a strategy allows one to minimize the initial capital cost of equipment, piping, well capacity, etc. An annual geothermal-energy contribution in the range of $70 z$ to $\sim 948$ of the space heating was chosen as an appropriate system-sizing parameter.

The previously determined IC's may now be used to predict the energy requirements of the complex relative to the 
difference between the degree day base of $65^{\circ} \mathrm{F}$ and the ambient temperature. The energy demand, $E_{D^{\prime}}$ in $\mathrm{BTU} / \mathrm{hr}$, will be:

$$
E_{D}=\text { BIC }\left(65-t_{\text {ambient }}\right)
$$

It is next necessary to determine the relative frequency of occurrence of the various levels of ambient temperature through the scottsbluff winter. In Chapter 23 of retrofitting reference 3, winter design temperatures are defined for two levels. The 998 and $97 \frac{1}{2} 8$ design temperature values represent the temperatures which equalled or exceeded these portions of the total hours in the months of December, January and February (a total of 2160 hours). In a normal winter there would be approximately 22 hours at or below the 998 design value and approximately 54 hours at or below the $97 \frac{1}{8} 8$ value. For scottsbluff, the 998 value is $-8^{\circ} \mathrm{F}$ and the $97 y_{2} 8$ value is $-3^{\circ} \mathrm{F}$ (as previously mentioned).

In order to determine other levels of occurrence, weather data were obtained for scottsbluff from NOAA for December 1979, Jan. '80, Feb. 180, Dec. 180, Jan. '81, and Feb. 181. These data included ambient temperature recorded on three hour intervals. These data were analyzed using a "bin method" or histogram to determine the frequency of occurrence of temperaturesin $5^{\circ} \mathrm{F}$ increments.

A summary of the histograms is shown in Table 1. Figure 2 shows the percentage of time that different temperature "bins" 
Table 1. Relative Frequency of Ambient Temperatures for scottsbluff

\begin{tabular}{|c|c|c|c|}
\hline Ce11 \# & $\begin{array}{l}\text { Lower } \\
\text { Iimit }\end{array}$ & $\begin{array}{l}\text { Number } \\
\text { of OBS }\end{array}$ & $\begin{array}{l}\text { \& Relative } \\
\text { Frequency }\end{array}$ \\
\hline 1 & -15.00 & 1 & .50 \\
\hline 2 & -10.00 & 1 & .50 \\
\hline 3 & -5.00 & 3 & 1.50 \\
\hline 4 & 0.00 & 6 & 3.00 \\
\hline 5 & 5.00 & 8 & 4.00 \\
\hline 6 & 10.00 & 8 & 4.00 \\
\hline 7 & 15.00 & 17 & 8.50 \\
\hline 8 & 20.00 & 23 & 11.50 \\
\hline 9 & 25.00 & 26 & 13.00 \\
\hline 10 & 30.00 & 28 & 14.00 \\
\hline 11 & 35.00 & 2.5 & 12.50 \\
\hline 12 & 40.00 & 20 & 10.00 \\
\hline 13 & 45.00 & 12 & 6.00 \\
\hline 14 & 50.00 & 10 & 5.00 \\
\hline 15 & 55.00 & 6 & 3.00 \\
\hline 16 & 60.00 & 4 & 2.00 \\
\hline 17 & 65.00 & 2 & 1.00 \\
\hline
\end{tabular}




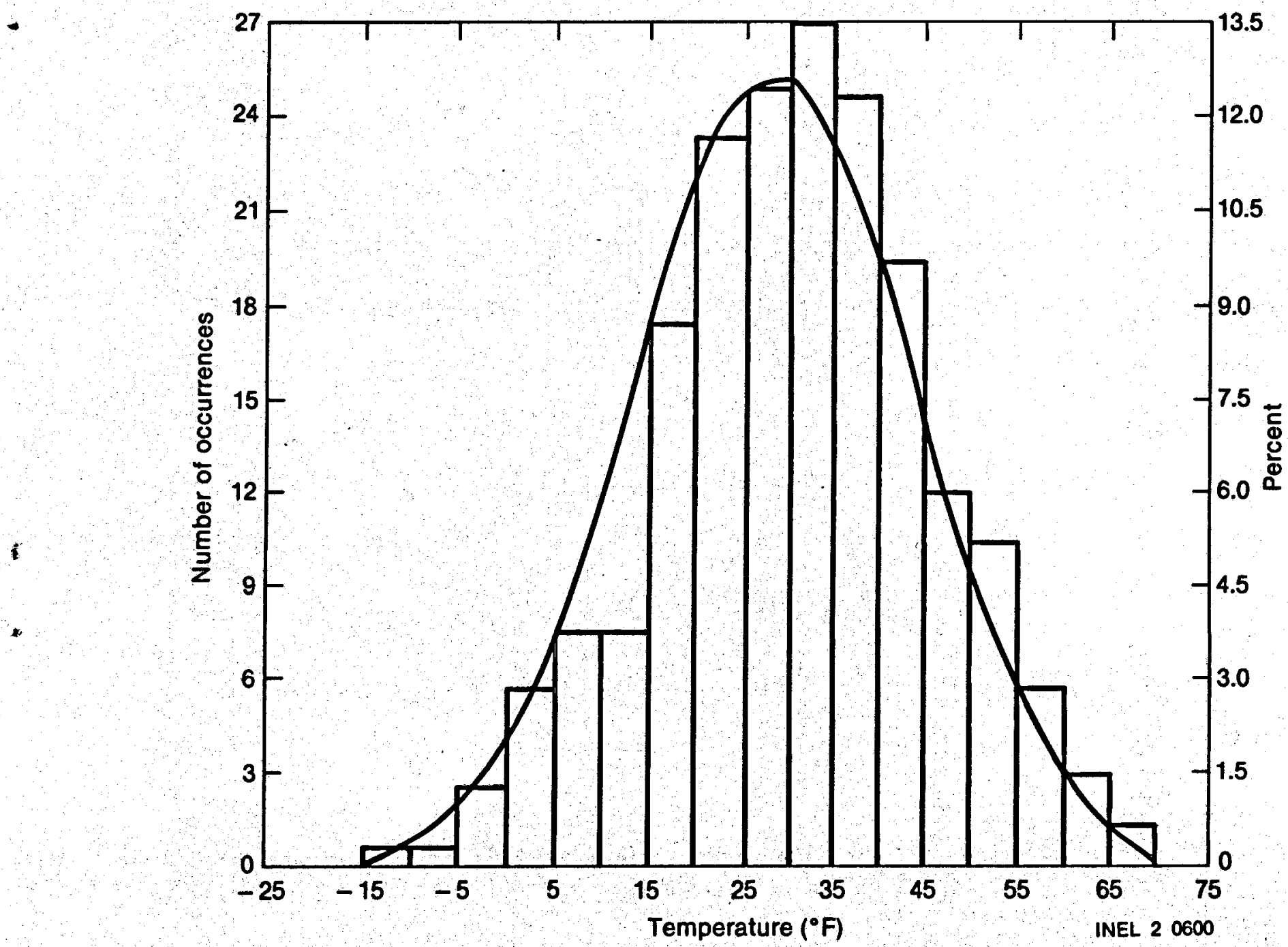

Figure 2. Three-month summary of winter temperature distribution, 1980-81. 
occurred using the combined 6-month data from the two heating seasons. These past two winters have been more mild than normal and yet the data shown in Table 1 correspond nicely with the ASHRAE 998 and $97 \frac{1}{2} 8$ design temperatures.

The percentage of relative frequency data from table 1 was then applied to the heating-degree-day data shown on Table 2. Dec., Jan., and Feb. combined represent 3393 DD or 508 of the average-annual total for scottsbluff. The statistical data of Table 1 can be plotted as in Figure 3. The parameter $\left(65-t_{\text {ambient }}\right.$ ) is plotted bersus the relative frequency (RF) of occurrence of this paramter. The dotted line $(a, b)$ corresponds to an outside temperature of $20^{\circ} \mathrm{F}$. From the relationship $\frac{\text { crosshatched area }}{\text { remaining area }}=\frac{\text { heating supplied by geothermal }}{\text { heating supplied by backup system }}$ one concludes that the fraction of heat which needs to be supplied by backup for this three-month period is about 88 . Since 508 of the annual degree days occur during this time it seems safe to say that 68 of the annual heating load would be backup heat if geothermal heating would handle the load down to $20^{\circ} \mathrm{F}$. We suggest doing this with the main load, but for the garage we would supply all of the heat from geothermal energy.

Sophisticated plate-type heat exchangers and other equipment make it economically feasible to utilize low-temperature geothermal energy for space heating. The geothermal resource is expected to be above $180^{\circ} \mathrm{F}$ : A design goal is to extract the maximum amount of energy from the geothermal resource; 
Insolation and Temperature Data

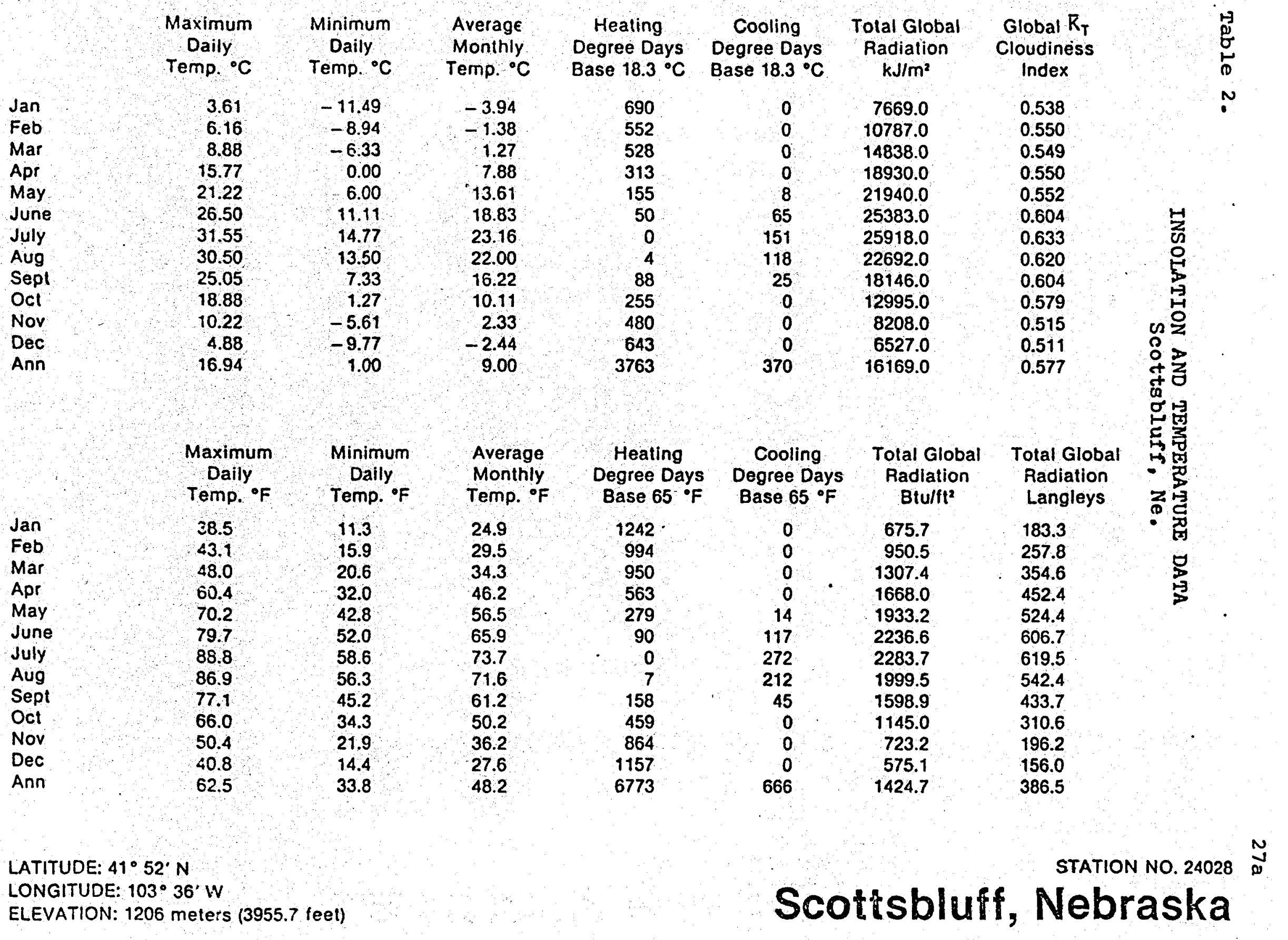




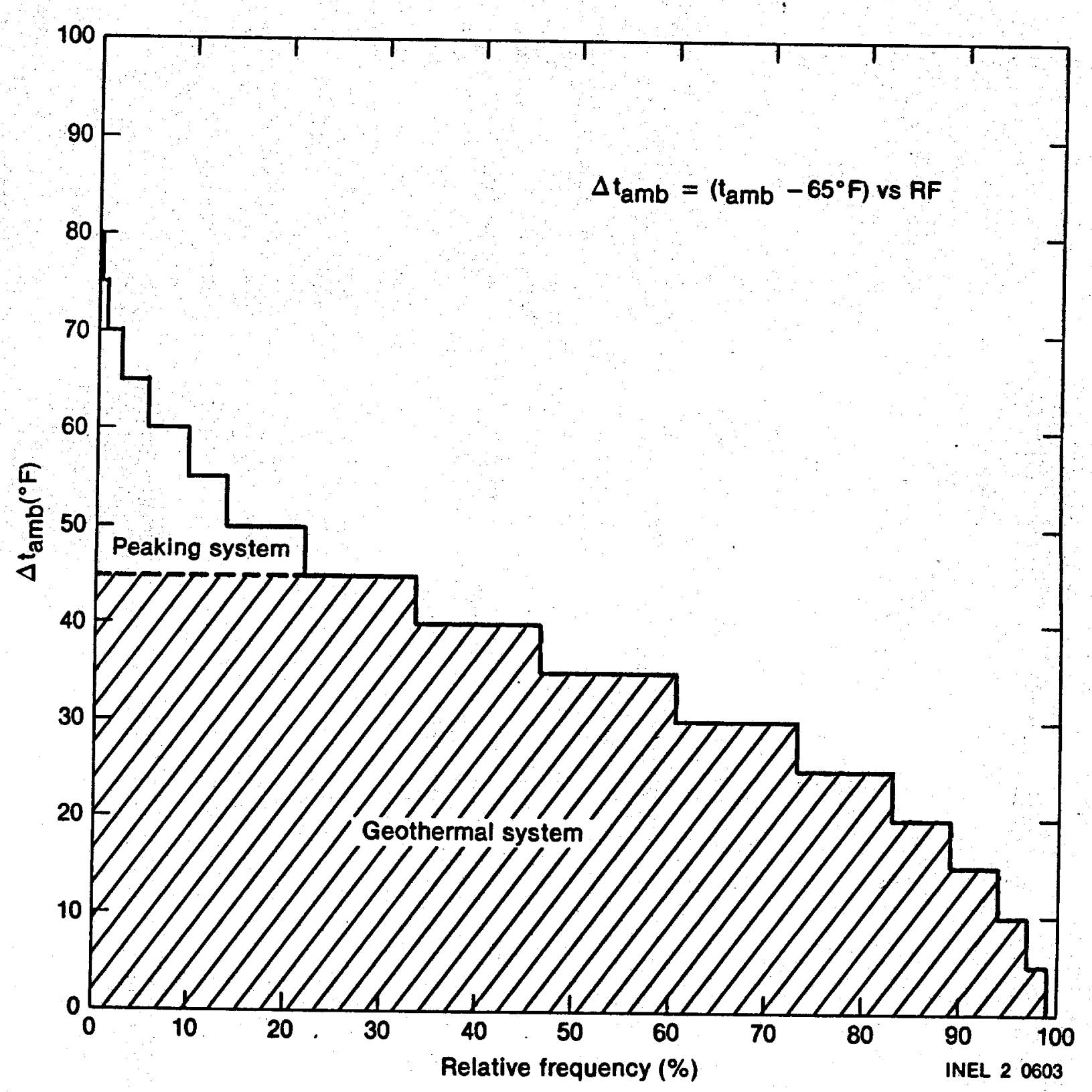

Figure 3. Plot of ambient temperature and the relative frequency for December; January, and February. 
thereby minimizing pumping requirements, and st111 allowing use of most of the terminal equipment of the existing mechanical system (which is typically designed for a $20^{\circ} \mathrm{F}$ temperature drop). The practical limit may be to expect a temperature arop of $40^{\circ} \mathrm{F}$ in the geothermal resource from $180^{\circ} \mathrm{F}$ to $140^{\circ} \mathrm{F}$ by circulating some or all of the hot water in the heating system through two terminal units in series. Our first study will assume that the existing distribution system will be used except for the garage where we will assume a heated floor. Thereafter we will see what happens if we add additional radiators. We will try to satisfy all the heat for the garage, but will only carry the main load down to $20^{\circ} \mathrm{F}$ ambient. Using this assumed temperature arop the flow rate needed to carry the main load is then determined by the following relation:

$$
m=\frac{E_{D}}{(d)(60)(\Delta T)}
$$

where

m = mass flow rate in GPM

(d) = density of the geothermal fluid (assume $8.33 \mathrm{lb} / \mathrm{gal}$. )

$\Delta \mathrm{T}=$ temperature drop of geothermal fluid $=40^{\circ} \mathrm{F}$.

To carry the main load down to $20^{\circ} \mathrm{F}$, the energy demand ( $E_{D m L}$ ) is

$$
\begin{aligned}
E_{D M L} & =(M L C)(65-20)=6.79 \times 10^{4} \times 45 \frac{\mathrm{BTU}}{\mathrm{hr}} \\
& =3.06 \times 10^{6} \frac{\mathrm{BTU}}{\mathrm{hr}} \\
\mathrm{m} & =\frac{3.06 \times 10^{6}}{(449.8)(40)}=153 \mathrm{gal} / \mathrm{min} .
\end{aligned}
$$


By choosing a mass flow rate of 150 GPM and assuming a $40^{\circ} \mathrm{F}$ drop in temperature through a heat exchanger, $3.0 \times 10^{6}$ BTU/hr would be supplied. This would meet the energy requirements of the complex down to an ambient temperature of slightly above $20^{\circ} \mathrm{F}$. According to Figure 3 and previous assumptions, this would represent approximately 928 of the heating requirements for Dec., Jan., and Feb and most of the heat required for the remaining winter months to yield an annual contribution of approximately 948 . This peak delivery rate of 150 GPM will be used in the next phase of our study.

4. Utilization of the Geothermal Resource in the Buildings. Ironically, the limiting factor in extracting heat from the geothermal fluids is the heat-distributing system which is sized to operate between $180^{\circ} \mathrm{F}$ and $140^{\circ} \mathrm{F}$. This means the main load can only develop a drop of $40^{\circ} \mathrm{F}$ in the geothermal fluids during full operation. However, during warmer days the system can be operated at much lower temperatures, yielding a greater utilization of the geothermal fluids and thus cutting the cost of pumping the geothermal fluids.

We define the symbols:

$$
\begin{aligned}
& \Delta T_{\text {ambient }}=65^{\circ} \mathrm{F}-\mathrm{t}_{\text {ambient }} \\
& \mathrm{f}=\frac{65^{\circ} \mathrm{F}-\mathrm{t}_{\text {ambient }}}{45^{\circ} \mathrm{F}} \quad \text { fraction of full load for } \\
& \text { main distributing system. }
\end{aligned}
$$




$$
T_{\text {op }}=72^{\circ} \mathrm{F}+f(160-72)^{\circ} \mathrm{F}, \mathrm{T}_{\text {ret }}=72^{\circ} \mathrm{F}+f(140-72)^{\circ} \mathrm{F}
$$

mean operating temperature and return-water temperature of main heating system under partial load.

$$
\begin{array}{ll}
\Delta \mathrm{T}_{\text {gar }} \Delta \mathrm{T}_{\text {ht.wt. }} & \text { Temperature drops in geothermal fluid due } \\
& \text { to heating of garage and service hot water. } \\
\mathrm{T}_{\text {inj }} & \text { Injection-water temperature. }
\end{array}
$$

The figures in Table 3 represent a highly-idealized model of the system's behavior. However, the parameters show the general trend and one can arrive at averages* of $\mathrm{T}_{\mathrm{Op}}, \mathrm{T}_{\text {inj }}$, and $\dot{\mathrm{m}}$. The thermal inertia of the building is not considered in the averaging.

Next, we will add a distribution system with a capacity such that one million BTU/hr are delivered at an average operating temperature of $130^{\circ} \mathrm{F}$. Under these conditions the main heating system needs to operate at $2 / 3$ of full load and so $T_{\text {op }}-130 \mathrm{~F}$. The return-water temperature for the main load would then be $\sim 120^{\circ} \mathrm{F}$. The $\Delta \mathrm{T}$ for the geothermal fluid then becomes about $60^{\circ} \mathrm{F}$ and $\mathrm{m}=\frac{3.05 \times 10^{6}}{500} \times 100 \mathrm{gal} / \mathrm{min}$ would be the maximun pumping rate.

Table 4 sumarizes the effects of this strategy for the three coldest months.

* Average of quantity $\langle Q\rangle=\frac{\sum_{i} R F_{i} Q_{i}}{\sum R F_{i}}$ 


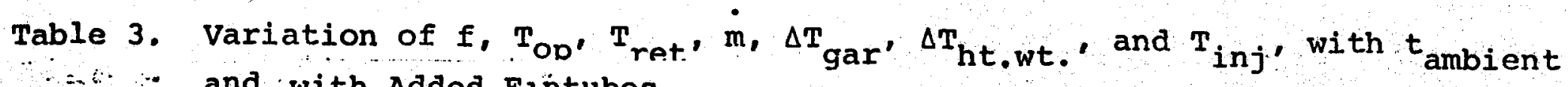
$\therefore$ and with Added Fintubes

\begin{tabular}{|c|c|c|c|c|c|c|c|c|c|}
\hline$t_{\text {ambient }}$ & $\mathbf{R F}$ & $\Delta \mathbf{T}_{\mathrm{amb}}$ & $\mathbf{f}$ & $T_{\text {op }}$ & $\mathbf{T}_{\text {ret }}$ & $\dot{\mathrm{m}}$ & $\Delta \mathbf{T}_{\text {gar }}$ & $\Delta \mathrm{T}_{\mathrm{h} t \mathrm{i} \mathrm{w}}$ & $T_{\text {inj }}$ \\
\hline-15 & .5 & 80 & 1.000 & 160 & 140 & 150 & 12.99 & 2.16 & 124 \\
\hline-10 &. .5 & 75 & & . & $\therefore \cdots$ & & 12.18 & & 124 \\
\hline-5 & 1.5 & 70 & & & & & 11.37 & & 126 \\
\hline 0 & 3 & 65 & & & & & 10.55 & & 127 \\
\hline 5 & 4 & 60 & & & & & 9.74 & & 128 \\
\hline 10 & 4 & 55 & & & & & 8.93 & & 129 \\
\hline 15 & 8.5 & 50 & & & & & 8.12 & & 129 \\
\hline 20 & 11.5 & 45 & 1.000 & 160 & 140 & 150 & $7.31^{\circ}$ & 2.16 & 130 \\
\hline 25 & 13 & 40 & 0.888 & 150 & 132 & 127.6 & 6.50 & 2.54 & 123 \\
\hline 30 & 14 & 35 & 0.777 & 140 & 124 & 85 & 5.69 & 3.81 & 115 \\
\hline 35 & 12.5 & 30 & 0.666 & 131 & 117 & 64.8 & 4.87 & 5.00 & 107 \\
\hline 40 & 10 & 25 & 0.555 & 121 & 109 & 47.9 & 4.06 & 6.76 & 99 \\
\hline 45 & 6 & 20 & 0.444 & 111 & 102 & 34.8 & 3.24 & 9.31 & 90 \\
\hline 50 & 5 & 15 & 0.333 & 101 & 94.3 & 23.8 & 2.44 & 13.6 & 79 \\
\hline 55 & 3 & 10 & 0.222 & 91 & 86.6 & 14.5 & 1.62 & 22.3 & 63 \\
\hline 60 & 2 & 5 & 0.111 & 81 & 78.8 & 10 & & & 63 \\
\hline 65 & 1 & 0 & 0 & 72 & 72 & 10 & & & 70 \\
\hline Average & & & & $137^{\circ} \mathrm{F}$ & $122^{\circ} \mathrm{F}$ & $93 \mathrm{ga}$ & $/ \min$ & & $112^{\circ} \mathrm{F}$ \\
\hline
\end{tabular}


Table 4. Variation of $f, T_{\text {op }}, T_{\text {ret' }} \dot{m}_{,} \Delta T_{\text {gar' }} \Delta T_{h t . w t . '}$ and $\mathrm{T}_{\text {inj }}$ with $t_{\text {ambient }}$ and with Added Fintubes

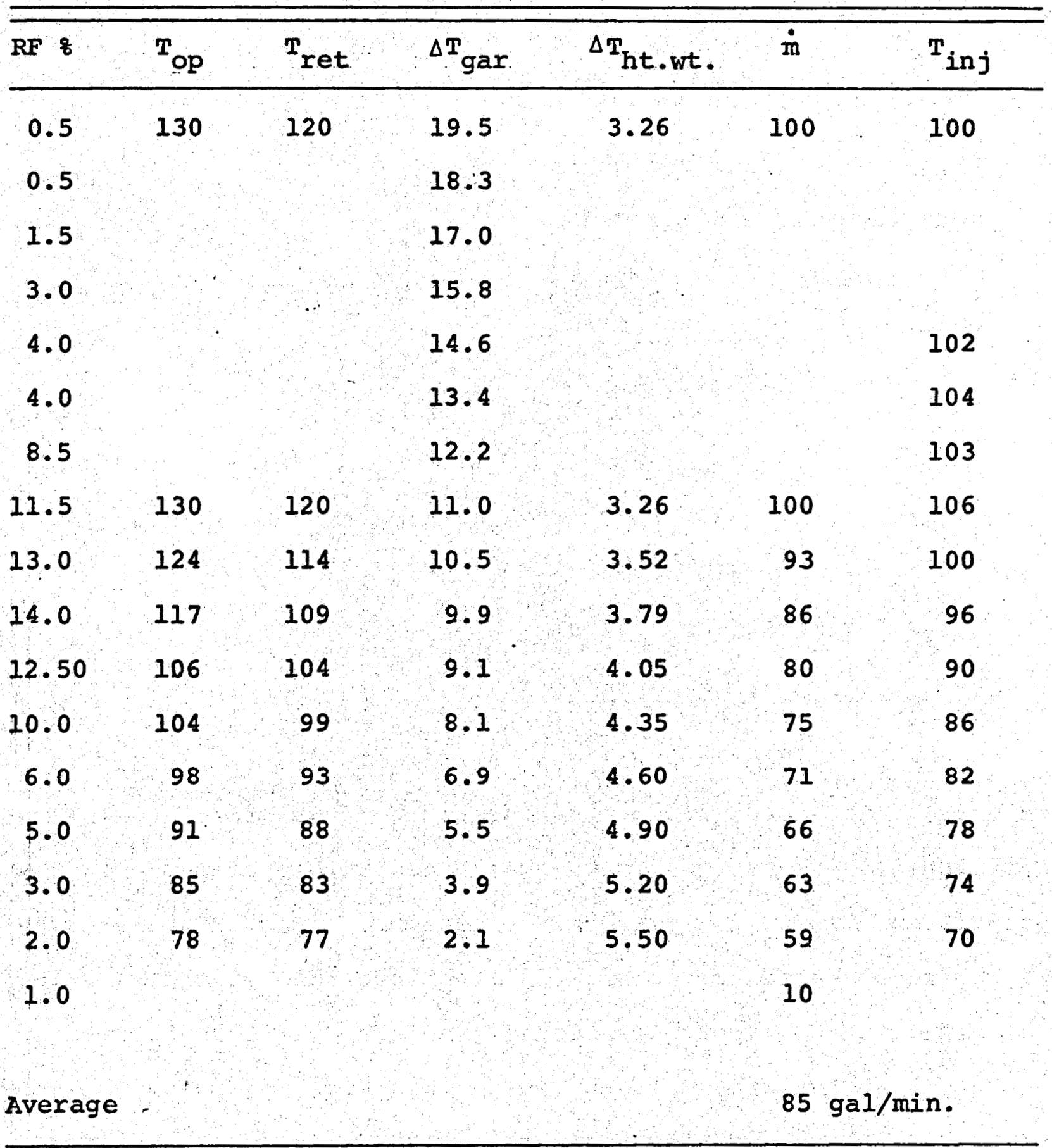


Next let us compute the effective temperature drop for the period covered by Table 1 by dividing the average energy demand by $500 \mathrm{in}$ so that

$$
\Delta T_{\text {eff }}=\frac{E_{D}}{500 \dot{m}}
$$

The fuel use for that period is

Auto Tech $\quad 3,511,800 \mathrm{ft}^{3}$

M.B. + Dorm $15,684,100 \mathrm{ft}^{3}$

Hot water $89,500 \mathrm{ft}^{3}$

$$
20,090,900
$$

Minus

peaking fuel $1,240,000$

We get $\quad 1.855 \times 10^{7} \mathrm{ft}^{3}$ and from this the energy demand of $3.24 \times 10^{6} \mathrm{BTU} / \mathrm{hr}$.

$$
\begin{aligned}
& \Delta T_{\text {eff }}=75^{\circ} \mathrm{F} \text { at } 85 \mathrm{gal} / \mathrm{min} . \\
& \Delta T_{\text {eff }}=68^{\circ} \mathrm{F} \text { at } 95 \mathrm{gal} / \mathrm{min} .
\end{aligned}
$$

A rough estimate for the average flow rates for sept. through April yields figures of the order of $60 \mathrm{gal} / \mathrm{min}$. The differences between the two cases are negligible compared to the errors involved in the estimation procedure. For this flow rate we arrive at an effective $\Delta T=80^{\circ} \mathrm{F}$. Since this figure is used to calculate the electricity costs, the error will be carried forward into that phase of the work. However, we expect to overestimate the costs by using this figure. The conclusion here is that the pumping costs for the larger (150 GPM) and 
smaller (100 GPM) maximum pumping rates are pretty much the same. It should be noted that a 150 GPM flow rate implies a larger pump (see Appendix B).

closer analysis shows that the costs of installing a larger pump versus adding more terminal units in the form of perimeter fin tubes offset one another. It is still advisable to use the smaller pump since it is easier to handle, and the surges of water are not as great and not as powerful. Fintubes were used because of the ease of estimating the costs--other alternatives, particularly preheating the air for the ventilating units should be considered in the final engineering design.

With the above as a background to general utilization of the geothermal resource in the buildings, the existing mechanical system was evaluated using equipment lists for each of the three buildings in the complex.

a. The Administration and Classroom Building. This building utilizes a central system with a $5050 \mathrm{MBH}$ hot water boiler for heating and a 300 Ton Chiller for cooling. It is assumed that a four pipe system is used to run either hot or chilled water to various terminal units.

The terminal units are of three different kinds. The first group is large air handling units (A.H.U.) assumed to be multi-zoned with an outdoor air supply and integral heating and cooling coils. The combined rated capacity of the 10 A.H.U.'s 
is approximately $5600 \mathrm{MBH}$ based on an entering water temperature (E.W.T.) of $180^{\circ} \mathrm{F}$ and a $20^{\circ} \mathrm{F} \Delta T$.

The second type of terminal unit is the unit yentilators. These are assumed to be cabinet type with heating and cooling . coils, motor and fan and a return-air--outside-air mixing section. These units are rated for heating at a $180^{\circ} \mathrm{F}$ E.W.T. and a $30^{\circ} \mathrm{F} \Delta \mathrm{T}$ drop. The combined rated capacity of these units is approximately $1250 \mathrm{MBH}$.

The third type of unit is the room air conditioner. It is assumed that this unit consists of a cabinet with heating and cooling coils, motor, fan and filter and that it uses 1008 return air. The combined rating of these units is approximately $440 \mathrm{MBH}$ (rated E.W.T. unknown) based on a $30^{\circ} \mathrm{F} . \Delta \mathrm{T}$.

From these ratings it may be seen that the terminal units are approximately 508 oversized compared to the boiler capacity. Based on a conversation with one of the operating engineersiat Nebraska Western Community College, it is assumed that the mass flow rate through the boiler is 530 GPM (pump P-3 and P-4) and that load control is obtained by controlling boiler-water output temperature. A $40^{\circ} \mathrm{F}$ rise across the boiler is normal in operation of the system.

b. Dormitory. The mechanical system in the dorm is envisioned to use a combination central heater/chiller unit to supply energy to supply heated or chilled water to terminal equipment consisting of two A.H.U.'s and four-fan coil units. 
The central unit is rated for $600 \mathrm{MBH}$ heating and 25 Tons for cooling. The terminal units have a combined rating of $586 \mathrm{MBH}$ based on a $160^{\circ} \mathrm{F} \mathrm{E.W.T.} \mathrm{and} \mathrm{a} 20^{\circ} \mathrm{F} \Delta \mathrm{T}$.

In addition to this system the dorm also uses a gas-fired make-up air unit. This roof-mounted device is used in conjunction with seven exhausters to provide ventilation. The unit is rated at $375 \mathrm{MBH}$ heating and $273 \mathrm{MBH}$ cooling.

c. Garage and Motor Pool. This facility is conditioned by twelve roof-top units. All twelve are direct gas-fired airheating furnace-type units. Eight of the units are heating only while the remaining four are both heating and cooling units. The rated capacity of the units is $1072 \mathrm{MBH}$ heating with a leaving air temperature of $120^{\circ} \mathrm{F}$. The four cooling units are rated for $130 \mathrm{MBH}$ combined. It is assumed that these units heat separate zones with little or no distribution ductwork.

Each of the three main buildings in the complex work independently of each other for their heating and cooling needs.

5. Geothermal Resource/Mechanical System Interface. Conceptual development of the geothermal-resource substitution for the existing mechanical systems in the complex is based on the heating-cycle requirements. Section 7 will examine the potential for utilization of this system for cooling. The proposed concept assumes that the geothermal resource will be pumped from a source well into a combination surge tank--storage tank 
with appropriate pressure-relief device and flow-bypass control valve. From the storage tank, the geothermal water will be pumped through insulated, below-grade piping to the mechanical equipment room of the Administration-Classroom building. The geothermal resource will be circulated through a plate-type, liquid to liquid, heat exchanger made of stainless steel (Alpha-Laval or equal). Heat will be extracted from the geothermal resource by the hot-water heating-system return water as it is circulated in a counter-flow arrangement through the heat exchanger. The cooled geothermal discharge water will then be piped to a reinjection well or some other appropriate sink. This conceptual development assumes that load control for this systen will be accomplished by varying the mass-flow rate of geothermal water pumped through the heat exchanger. If the unit is rated for $150 \mathrm{GPM}$ of geothermal flow, a control valve will be used to throttle down this flow during periods of lower heating demand. The effect of this will be to lower the exit temperature of the heated water which will directly lower the rate of heat transfer at the terminal unit.

This control philosophy might make it feasible to use a large, well-insulated storage tank into which the geothermal resource could be pumped by the deep-well pump. The geothermal water could then be puraped to the heat exchanger as needed. Careful sizing of the tank might make it possible to reduce the size of the deep-well pumping unit, thereby reducing the need to 
bypass the deep-well output during periods of reduced load or cycling of the unit. This could reduce initial capital costs. The tank should be sufficiently large so that its capacity could be drawn down during the colder winter months. Its capacity could be replenished during light-load periods or during backup operation of the existing gas system. This possibility should be explored in a detailed engineering study but is mentioned here as a point of information.

This report assumes that the geothermal-system plate heat exchanger will be installed in parallel with the existing hotwater boiler for the Administration--Classroom building to allow the existing system to be operated either as a peaking unit during periods when the demand is greater than the geothermal fluids can supply, or as a backup unit.

6. Retrofit Measures and costs. The following modifications are proposed as one way in which conversion to a geothermal energy supply could be accomplished. The proposal is based on extracting thermal energy from the geothermal supply and then distributing the heated water to all three buildings on the campus. Please refer to Figure 4 for a description of the proposed changes.

As previously mentioned, the geothermal energy will be extracted using a plate-type heat exchanger (HX-1) piped in parallel with the existing gas-fired boiler. A central controller sensitive to ambient-temperature conditions will regulate 


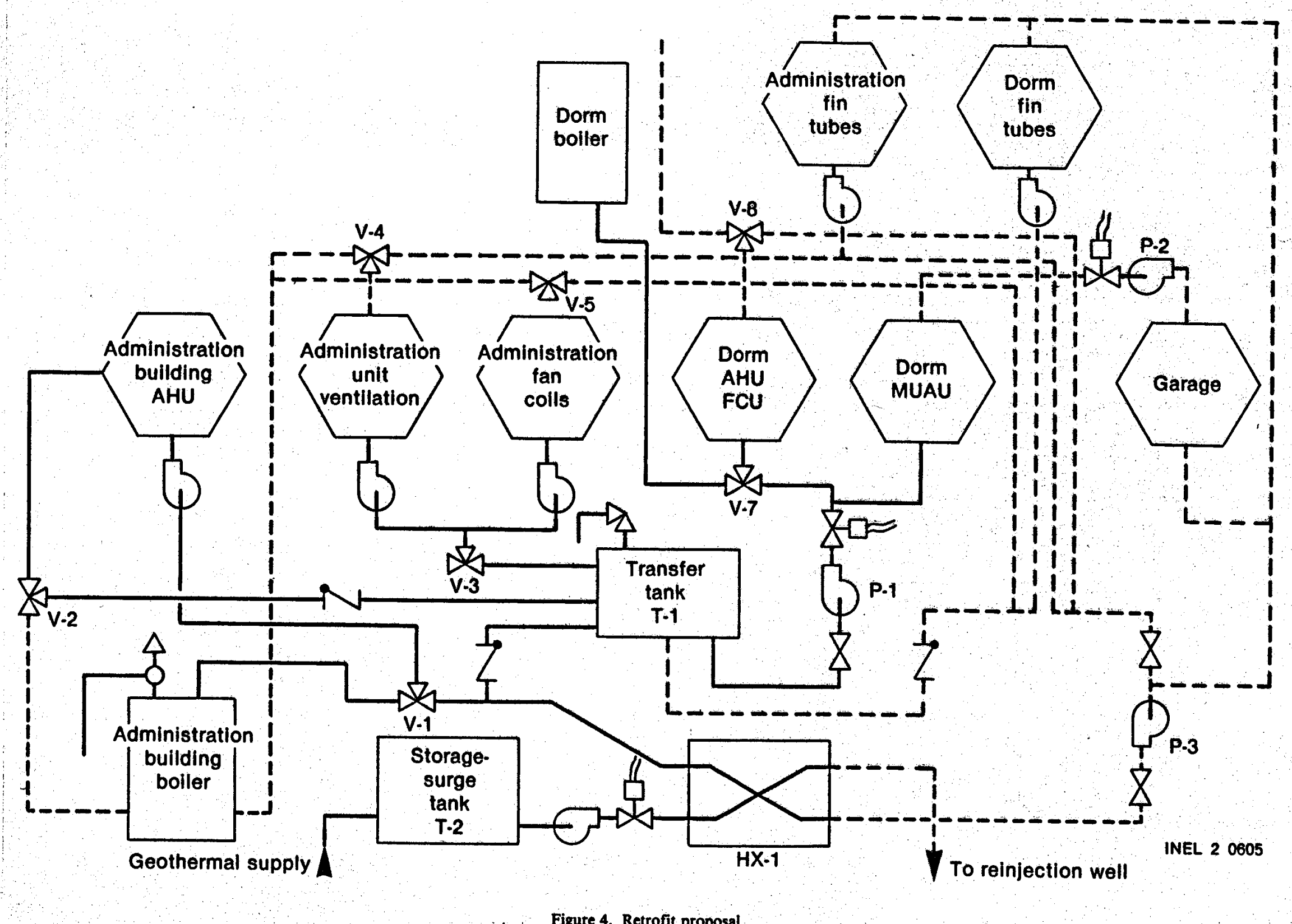


a series of 3-way flow-control valves to direct supply and return hot water to the appropriate heat source.

System operation using the geothermal energy source will circulate heated water from $\mathrm{HX}-1$ and transfer tank $\mathrm{T}-1$ to the Air Handling Units (AHU's) in the Administration Building using the existing supply pumps to the AHU's. The return water from these units will be directed through control valve $v-2$ into the tank T-1. The existing supply pump for the Administration Building unit ventilators and air conditioning units will draw hot water from tank $T-1$ through control valve $v-3$ for distribution to the terminal units. The return water from these units will circulate through control valves $\mathrm{V}-4$ and $\mathrm{v}-5$ to the return header line. The supply and return piping to and from the terminal units will remain the same.

Hot water will be pumped to the Dormitory and the Garage Building via insulated underground piping. Pump $P-1$ will pump water from the tank $T-1$ to the Dormitory. In the Domitory, some of the supply water will be piped directly to a heating coil added to the Make Up Air Unit (MUAU). The remaining hot water will be circulated through control valve $V-7$ to the $A H U$ and Fan coil unit (FCU) using the existing lines. Return from AHU's and the FCU's will pas's through control valve $\mathrm{y}-8$ and will return with the discharge from the MUAU back to the return header.

Because the Garage will be modified for floor-heating, cooler water can be used to heat that facility. Thus water which 
exits from the Dormitory and Administration fan coil units will be pumped by pump $\mathrm{P}-2$ to the Auto Tech building. This water will heat the classroom portion of the Autho Tech building with perimeter heating and then will heat the concrete slab. The floor will be modified by laying an interconnected grid of pipes onto the existing floor and then pouring three mitres of concrete on top of it.

This arrangement will permit the existing hot-water coils to be used as they are. During peak demand periods, the various 3-way flow-control valves will revert to use heat from the existing boilers. In the case of the MUAU in the Dormitory the existing system will be controlled by the 2 nd and 3 rd stage of a three-stage thermostat. Flow-control valves in the geothermal energy supply line will provide control of the hot-water flow rate. It is assumed that such control mechanisms exist in the hot-water heating supply lines to the existing hot water coils. The hot-water coils added to the MUAU in the Dorm should be sized to yield the needed heat-transfer rates for the expected entering water temperature (EWT) of the geothermal-heated water at full geothermal-load conditions. In addition to the above, water leaving the AHU's of the Administration building and Dormitory can be pumped through fintubes before being returned to $\mathrm{p}-3$. The estimated costs for these modifications are based on general estimates of the required piping, hangers, insulation, field welds, etc. 
Labor and materials costs are based on prices recommended in the construction estimating standards for mechanical systems outlined in Reference 4 . Labor cost is estimated to be $\$ 17 / \mathrm{hr}$ based on a composite crew.

\section{Administration and Classroom Building Modification}

a) (T-1) $500 \mathrm{Gal}, 125$ psi steel tank, installed $\$ 1,440$

b) Equipment Isolation Valves, installed $\$ 1,200$

c) $(\mathrm{P}-3) 5 \mathrm{HP}$ pump, installed $\$ 2,700$

d) 3-way Control valves (v-1 to $v-5)$, installed $\$ 5,000$

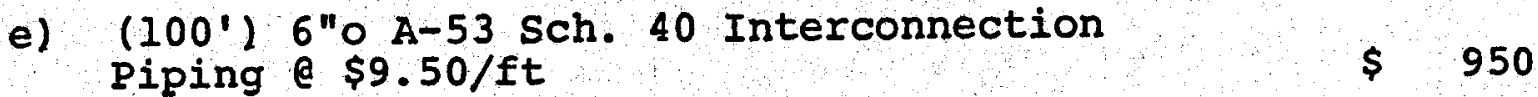

f) Pipe Fittings and Hangers $\$ 1,900$

g) Pipe Insulation \& $\$ 8 / \mathrm{ft}, 1 \frac{3}{2}$ " thick $\$ 800$

h) Piping Butt welds- -20 e $5 \frac{1}{2} \mathrm{hr}$ each $\$ 1,870$

i) Central Controller, installed $\$ 2,000$

j) $(1001) 3^{\prime \prime} \circ \mathrm{A}-53 \mathrm{sch} .40$ Interconnection
Piping e $\$ 3.40 / \mathrm{ft}$

k) Pipe Fittings and Hangers for $3^{10} 0 \quad \$ 800$

1) Pipe Insulation for $3^{\prime \prime}$ Pipe e $\$ 5.20 / \mathrm{ft} \quad \$ \quad 520$

m) $3^{\text {"o }}$ welds $\mathrm{a} 2.8 \mathrm{hr}$ each $\times 20 \quad \$ 950$

n) $T(2) 1000 \mathrm{gal}$ tank $\$ 2,000$

o) (P-4) 5 HP Pump, installed $\$ 2,700$

Subtotal $\$ 25,170$ 
Dormitory Modification

a) (P-1) 3 HP Purm, installed $\$ 2,100$

b) Isolation valves $\$ 1,000$

c) Flow Control valves $(\mathrm{V}-\mathrm{T}$ to $\mathrm{V}-9) \quad \$ 3,000$

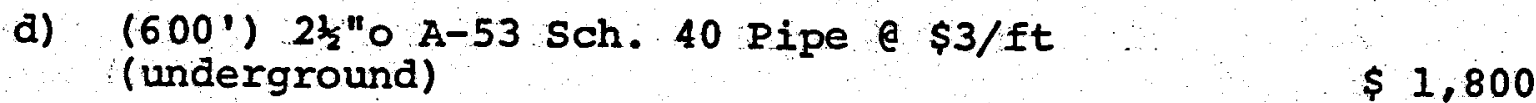

e) 50 welds $\$ 3$ hrs each $\$ 2,550$

f) $1 \frac{1}{2}$ in. Insulation and Plastic Jacket $09.25 /$ ft $\$ 925$

g) Fittings and Thrust Blocks $\quad \$ \quad 500$

h) Trenching and backfill $\$ 1,000$

i) (400') $2 \frac{1}{2} " \circ \mathrm{A}-53 \mathrm{Sch} .40$ inside pipe e $\$ 3.90 / \mathrm{ft} \$ 1,560$

j) Fittings and Hangers $\$ 1,200$

k) Welds--60 e 3 hrs each $\$ 3,060$

1) Insulation \& $\$ 4.75 / \mathrm{ft} \quad \$ 1,900$

meating Coil and Duct Transition for MUAU,
installed

n) AHU Controller, installed $\$ 500$

Subtotal $\$ 22,600$ 
Garage Modifications

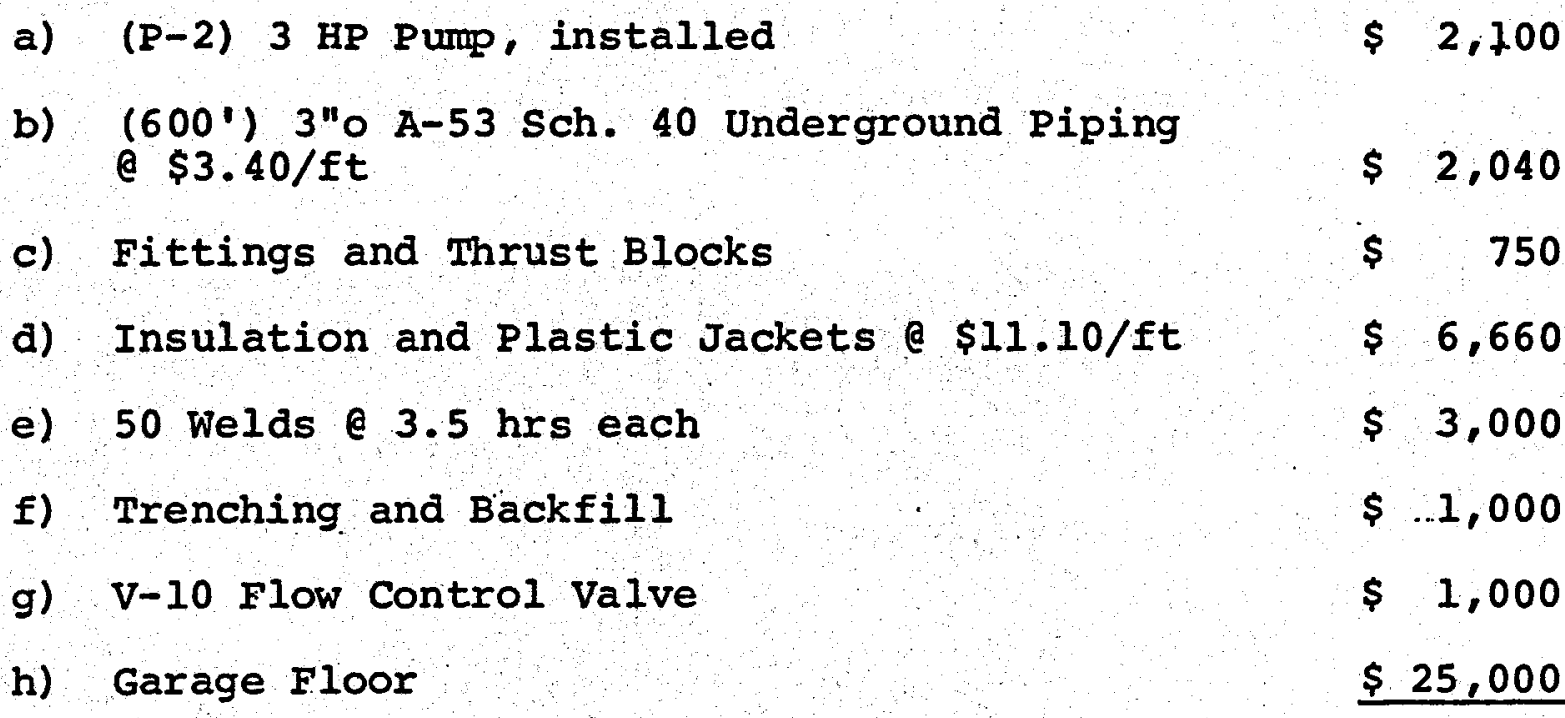

Subtotal $\$ 41,550$

Total $\$ 89,000$

Additional Fin Tubes for Entire Complex $\$ 27,000$

GRAND TOTAL $\$ 116,000$

7. Cooling Assessment. The Trane Chiller unit used for cooling of the Administration building is rated for 300 Tons of cooling capacity. It is assumed that this absorption unit requires a minimum input temperature of $160^{\circ} \mathrm{F}$ and operates at an efficiency (COP) of 0.6 . Cooling the geothermal resource from $180^{\circ} \mathrm{F}$ to $160^{\circ} \mathrm{F}$ would yield $1500 \mathrm{MBH}$ at $150 \mathrm{GPM}$. The required full-load demand for the chiller is $7200 \mathrm{MBH}$. Such a contribution is assumed to be impractical. It may be possible to use the geothermal resource to supply the 25 Ton Arkla chiller for the Dormitory. The usefulness of doing this depends on the 
frequency of occupancy of the Dormitory in the summer time. Modifications would basically involve a similar strategy as used in providing geothemal space heating to the Dormitory. Supply and return lines would be piped from the plate heat exchanger underground to the Dorm where the lines could be tied in parallel to the existing gas fired input. This modification is estimated to cost $\$ 15,000$. It may be possible to use the proposed heating supply and return line for the cooling load also with appropriate flow control valves. This option is estimated to cost $\$ 8000$.

\section{y. Cost-Benefit Analysis for Geothermal}

\section{Resources}

In Appendix B will be found the details for estimating costs and income for selected years of the period 1981-2000. Also included are the assurptions inherent in sizing the pump.

The cost-benefit analysis in the appendix is in terms of 1980 dollars and needs to be corrected for inflation. The inflation was assumed to be as follows: .1981--108; '82--98; '83--88; 184--78; $85--68 ; 186--58$, and 58 per year thereafter. These figures seem to be in line with the most optimistic goals of the present government. The expenses do not include interest expenses. Various scenarios of interest have been explored and are displayed graphically in Figure 5. On the left is plotted the indebtedness assuming continuous payments of the debt and interest from savings. Curves $A, B$, and $C$ are for $0 \&, 68$ and 108 interest. Curve $D$ is the expected payback if the construction 


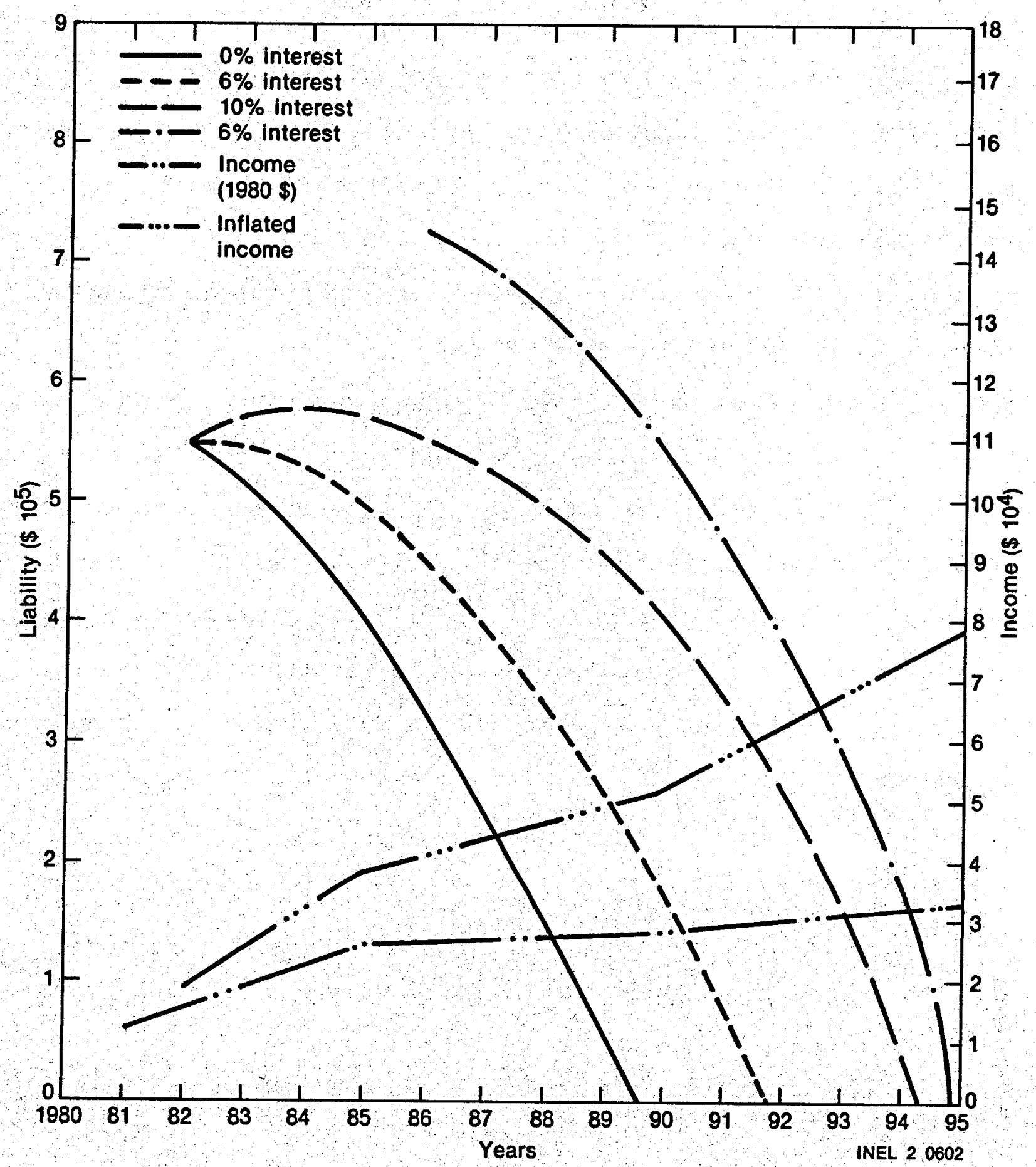

Figure s. Cost benefits for geothermal energy. 
is postponed until 1986 and assumes a 68 interest rate. Curve $E^{*}$ is projected net income from operations in 1980 dollars and Curve $F^{*}$ is the inflated income. For $08,6 \%$ and $10 \%$ interest: rates the payback period is 9,10 and 13 years respectively. Postponing the construction, as for Curve $D$, will not change the payback period to any great extent since construction cost will then be inflated to about $\$ 750,000$.

Figure 6 shows the cost benefits under the assumption that the well can pump $150 \mathrm{gal} / \mathrm{min}$ and that the equivalent of $9 \times 10^{4}$ CCF of energy can be sold. This means going to a larger purp and capital costs would be about $\$ 40,000$ greater. The value of the heat was calculated in 1980 gas prices and escalated with electricity costs and inflation. A customer should find this to be an attractive alternative. Note that this brings the payback period for $0 \%$ and $10 \%$ interest to 6 and 9 years respectively.

It seems that if the interest rates of the order of 68 (not impossible historically for tax-exempt investments) are available then the figures speak for developing the geothermal energy resource. The sale of the excess energy, if the well can be developed to deliver 150 GPM makes this a yery attractive alternative.

*The kinks in the curyes are artifacts introduced by linear interpolation of fuel costs. 
7

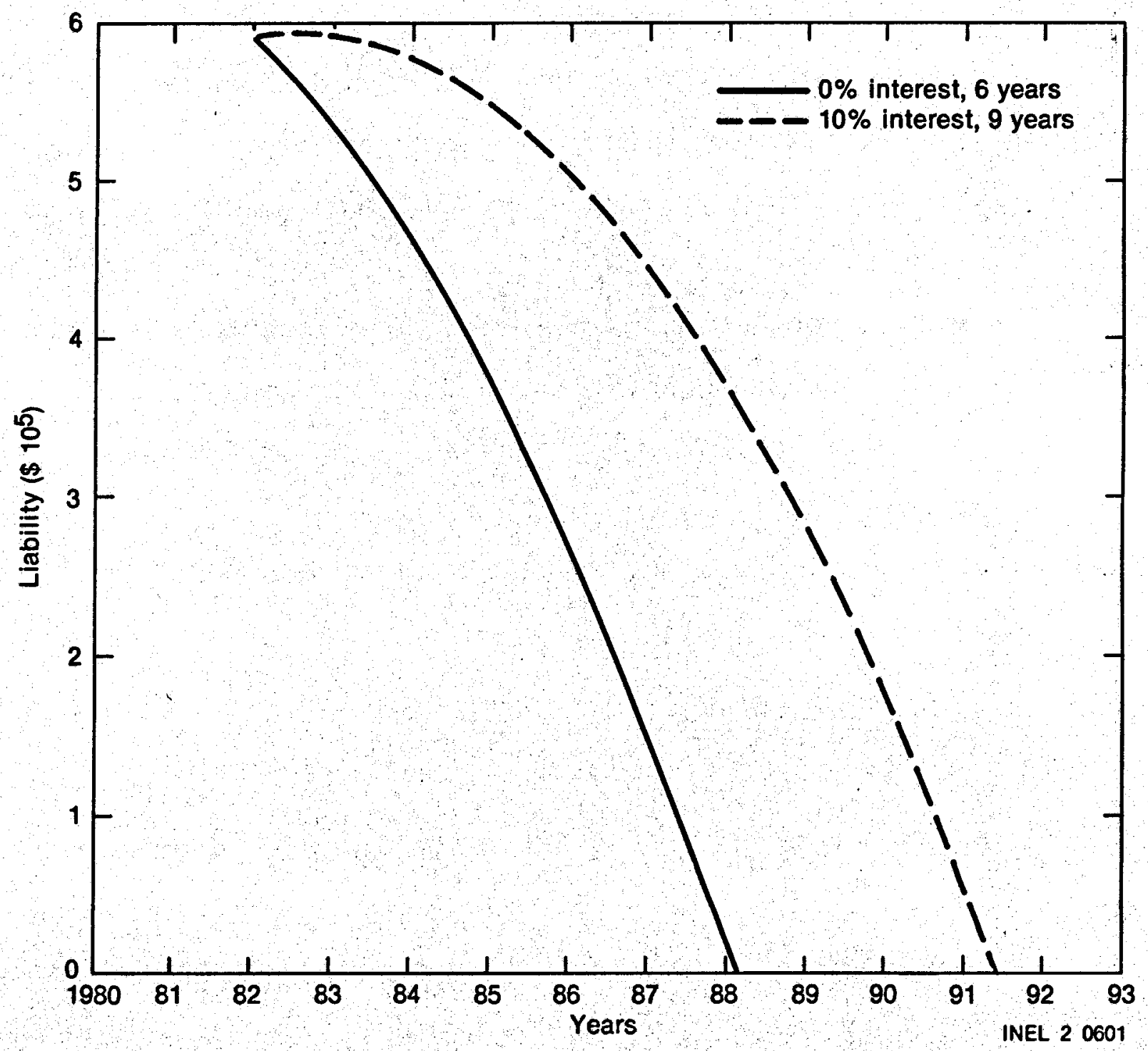

Figure 6. Cost benefits assuming sale of energy, 90,000 therms. 


\section{Energy Alternatives Exclusive of Geothermal}

A. Energy/Management/Conservation

The following recommendations are made for consideration.

1. Use of flexible curtains and exhaust piping in garage overhead doors. Reduces infiltration associated with truck egress and exhaust fumes.

2. Upgrade roof insulation levels where possible.

3. Using microprocessor control for load management.

4. Use of water conserving fixtures in every hot water outlet.

5. Add enthalpy controllers for ventilation control.

6. Add glazing to windows.

B. Cooling with Unconfined Groundwater

A brief examination of the potential for supplying a portion of the cooling requirements with unconfined groundwater was made. July weather data for 1979, 1980, and 1981 were secured (Appendix C). By examining the hourly weather conditions summary for each month, one can see averages for the hourly dew point temperature. By plotting those temps on the Psychrometric Chart (Appendix C) one can define the entry water temperature (E.W.T.) to the cooling coils that would provide some latent and sensible cooling effect. If the groundwater temperature is $59^{\circ} \mathrm{F}$ as measured, not much opportunity exists for a significant cooling contribution. E.W.T. below $60^{\circ} \mathrm{F}$ is required. 


\section{B. Heating/Cooling with Groundwater} Heat Pumps

The efficiency of heat pumps, as measured by their coefficient of performance (COP) is strongly temperaturedependent. As an example we will consider the TE079 which when installed in "tandem" can use water of about $60^{\circ} \mathrm{F}$ (about local shallow water temperature) and extract heat which it can deliver at $160^{\circ} \mathrm{F}$. The COP, however, is much greater at lower delivery temperatures, To. This is shown for the TE079* in Table 5.

We have the same problem with the mechanical system if one considers using groundwater heat pumps as we had with the geothermal resource.

The heat-distributing systems should be operated at the lowest possible temperature to get the largest COP. This problem can be solved in the same way as for the geothermal systems. The building alternative costs are about the same as for the geothermal system and would be of the order of $\$ 100,000$. Heat pumps, for instance, two TE079's connected in tandem were priced at $\$ 150,000$. The disposal of the used water could be effected by reinjecting in the winter and by disposing in an irrigation canal during summer.

A sample cost-benefit analysis is included, and the results for other years, after allowing for inflation and interest rates, are plotted in Figure 7 .

\footnotetext{
* Manufactured by Westinghouse.
} 
Table 5

Temperature Dependence of COP for TE079

\begin{tabular}{llllll}
\hline$T_{0}{ }^{\circ}$ & 1 & 160 & 140 & 120 & 110 \\
$C$ & 2.90 & 3.20 & 3.50 & 3.80 \\
\hline
\end{tabular}




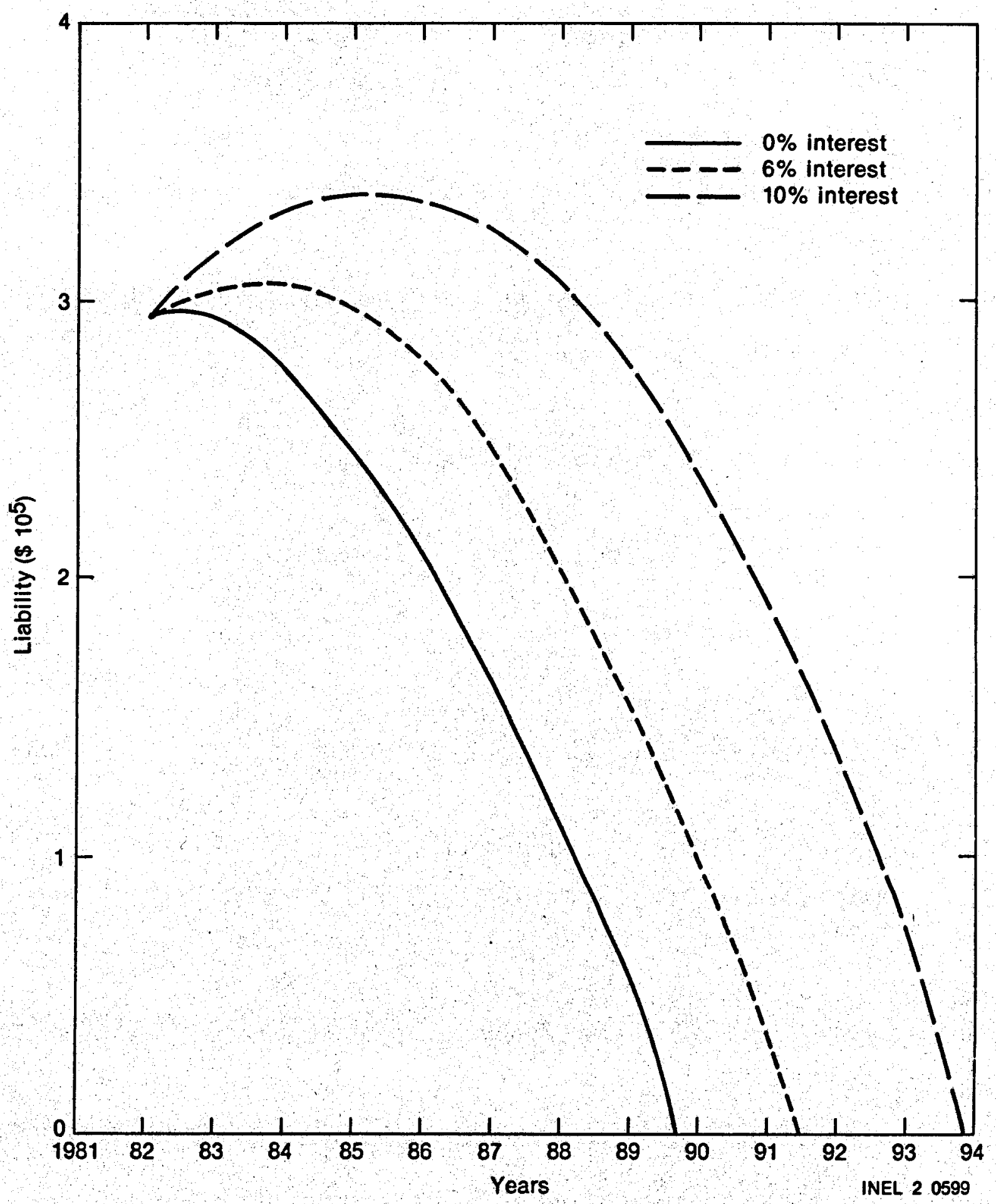

Figure 7. Heat pump cost benefits. 
Curve $A$ is without interest: 8 years payback. Curve B assumes 68 interest: 10 years payback. Curve $C$ assumes 108 interest: 12 years payback. These figures are somewhat encouraging, but one has to bear in mind that the life of the heat pump is estimated to be less than -15 years. The investments in the building's mechanical system will last longer.

Sample cost-Benefit Analysis for Heat Pumps

I. Capital Costs:

Two TE079 Ht. Pumps

$\$ 150,000$

Retrofit Bldgs. 110,000

Reinjection Well*

6,000

$\$ 266,000$

Engineering (108 of Cap. Costs)

26,600

Total Capital Costs

$\$ 292,600$

II. Average Annual Operating Expenses for 1981

Maintenance ( 48 of Cap. Costs)

cost of Electricity for Heating

$\$ 11,704$

Cooling (not known)

37,840

$\$ \quad 49,544$

III. Income

Gas Savings

$\$ \quad 45,673$

Cooling (Est. 308 of present)

4,000
$\$ 49,673$

Net Income before Interest

*Two production wells capable of delivering $400 \mathrm{gal} / \mathrm{min}$ exist. 


\section{Conclusions.}

Nebraska Western College has a physical plant located $5200 \mathrm{ft}$. above a low-temperature geothermal resource with attractive potentials for development.

We feel that flow rates of 100 to 150 gals. per minute of $180^{\circ} \mathrm{F}$ water can reasonably be expected and that the pump would probably be sited well above a depth of $3500 \mathrm{ft}$. The water is likely to be saline and thus would require reinjection. It is further expected that the geothermal fluids will contain chemicals that react with oxygen and thus it is recommended that any definitive engineering design isolate those waters from the atmosphere.

The retrofitting of existing structures is always problematical, but in this case the buildings can be adapted to geothermal heating with relatively minor changes in the existing heating system.

It should be noted that in several cases we have used our most pessimistic parameters in order to lend greater verisimilitude to our conclusions that the project has considerable viability. Even in the worst case scenario the project has some economic attractiveness.

The economic payback periods are predicated on rising gas prices and moderate inflation rates. Since payback periods of less than half the life of the installation are generally considered attractive, we feel that this could be a worthwhile 
project providing the interest rates are less than $10 \%$. If one could find another user to buy any excess capacity, the payback figures are downright attractive. With such a cost-share system, the economic projections for only seven to ten years take much of the uncertainty out of the conclusions.

The biggest uncertainty in this feasibility study is the well and the presence of sufficient flowrates to service the system. Only after arilling and testing the production well can we be certain of the economic benefits.

The alternative of applying heat pumps to shallow groundwater is marginally feasible. Groundwater is plentiful and quite warm for the region $\left(58^{\circ} \mathrm{F}\right)$. Heat pump technology would be very attractive in a region where fuel oil is the conventional energy form, but this technology does not compete very well with today's low natural gas prices.

Should Nebraska Western seriously consider exploring a geothermal system further, and anticipate hiring an engineering firm, it is recommended that the institution gather additional in-house information that will have a bearing on the final design. For this coming winter we recommend that a log be kept of the temperatures of the waters leaving the boilers and of the return-water temperatures. The thermometry should also be calibrated to insure valid readings. Flow rates of the circulating waters should also be determined. 
VIII. Appendices

\section{A. Questions from Nebraska Western College}

Nebraska Western College submitted a list of specific questions about a possible geothermal heating system with its request to E. G. \& G. for technical assistance. Most of these questions are addressed in detail in the feasibility study, Sections I-IV. The following is a summary response to those questions listed in Article II, Part 4 of subcontract No. K-7767.

a. The estimated capital cost for a geothermal installation for Nebraska Western College is $\$ 502,200$.

b. Various scenarios of payback are calculated in the report. Payback ranges from as little as 9 years with no interest to as much as 13 years with $10 \%$ interest on capital investment.

c. It is feasible to cool as well as to heat. The additional retrofitting cost would be about $\$ 15,000$.

d. One other heat source is mentioned in the text and that is the use of unconfined groundwater for water to water heat pumps. Efficient utilization of this heat source would require essentially the same modifications of the existing heat distribution system as with a geothermal system. The costs and paybacks are discussed in section VI. since the heat pumps are competing with gas, which is relatively cheap, payback periods are somewhat long when compared with the life of a heat pump. 
- f. It will require about one year for an operational system to be in place, considering the required bidding process for all stages of the project, including the detailed engineering. We would recomnend, however, that a test well first be drilled to determine presence of resource, temperature of resource, water quality and flow rate.

g. Compliance with local environmental codes would most likely include an injection well.

h. It cannot be entirely determined if adjacent facilities (i.e., high school and hospital) could tie into the project. This determination could be made after a test well is drilled.

i. The likelihood that the resource is hotter than geologists have estimated is small. However, the retrofit could accommodate temperatures approaching boiling temperatures. The improbable production of steam, however, would require a revision of retrofitting requirements and an upward revision of construction costs.

j. It is highly unlikely that a resource will be found at shallower depths than estimated. On the other hand it may be necessary to drill deeper than is estinated by several hundred feet which will require adjustments in drilling, casing and purp costs. 


\section{B. Geothermal Calculations}

\section{SIZING OF PUMP}

Sto

PUIP DEPTH

HEADLOSS/100FT

EXCESS HEAD

3500

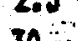

TOTAL HEAD

30

3617.5

\begin{tabular}{ll} 
ASSUHED PUHP-EFF.- & -.8 \\
FLOH RATE (GALS/MIN) & 150 \\
\hline PUIS HORSEPOHER & 171.456332 \\
ELCTR. POHER CONS.KUT & 127.906424 \\
ASSUHED ELECTR. PRICE/KUH & .0336
\end{tabular}

COST OF ENERGY CONSUHED BY THE PUMP PER KR:

THE USEFUL BTUH'S DEPEND ON THE TEMPERATURE DIFFERENCE BETUEEM THE FRESH

AND THE USED GEOTHERMAL FLUIDS

TEKP. DIFFEREHCE

KNH CONS. /BTUH DEL.

80

2.13177373E-05

\subsection{4}

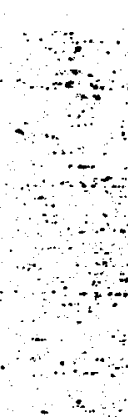

.

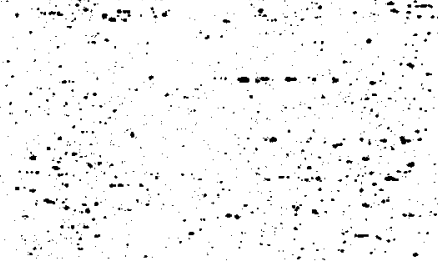




\section{costs}

1. capital costs

A, THE NELL

- DRILL \& TEST 65000

CASINE 1 FINISH. 80000

PUMP-INSTALLED $\quad 46400$

NELL BUILONE. $\quad 0$

HEAT EXCH. $\quad 16000$

PIPJNG FOR DISTRIB, 6000

TOTAL NELL 213400

8. THE INJECTION MELL

DRILLIHG

CASTHE 2 FIUISHIUS 10000

INJECTLON PUKP $\quad 2000$

TOTAL INJECT. NELL 107000

C. RETROFIT BLD65. 116315

D. ENGINEERING

15\% OF EQUIP.

NITHOUT INJ. UITH InJ.

19457.25

65507.25

TOTAL CAPJTAL COSTS

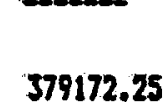

502222.25

FOR THEYEAR 1981

GAS PRICE ICCFI .262

ELECTR. PRICE /KWHE

i1. AYERAGe AHNUAL OPERATING EXPERSES

A. MaINTERALLE

9891.45

13101.45

3\% OF EQUIPT.

B. ELECTRICITY

10006.0574

(FOR PUMPING ONLY)

10452.7153

$\mp$

5

TOTAL AIL. OP.

19897.5074

23554.1653 
NET ANNUAL INCOME

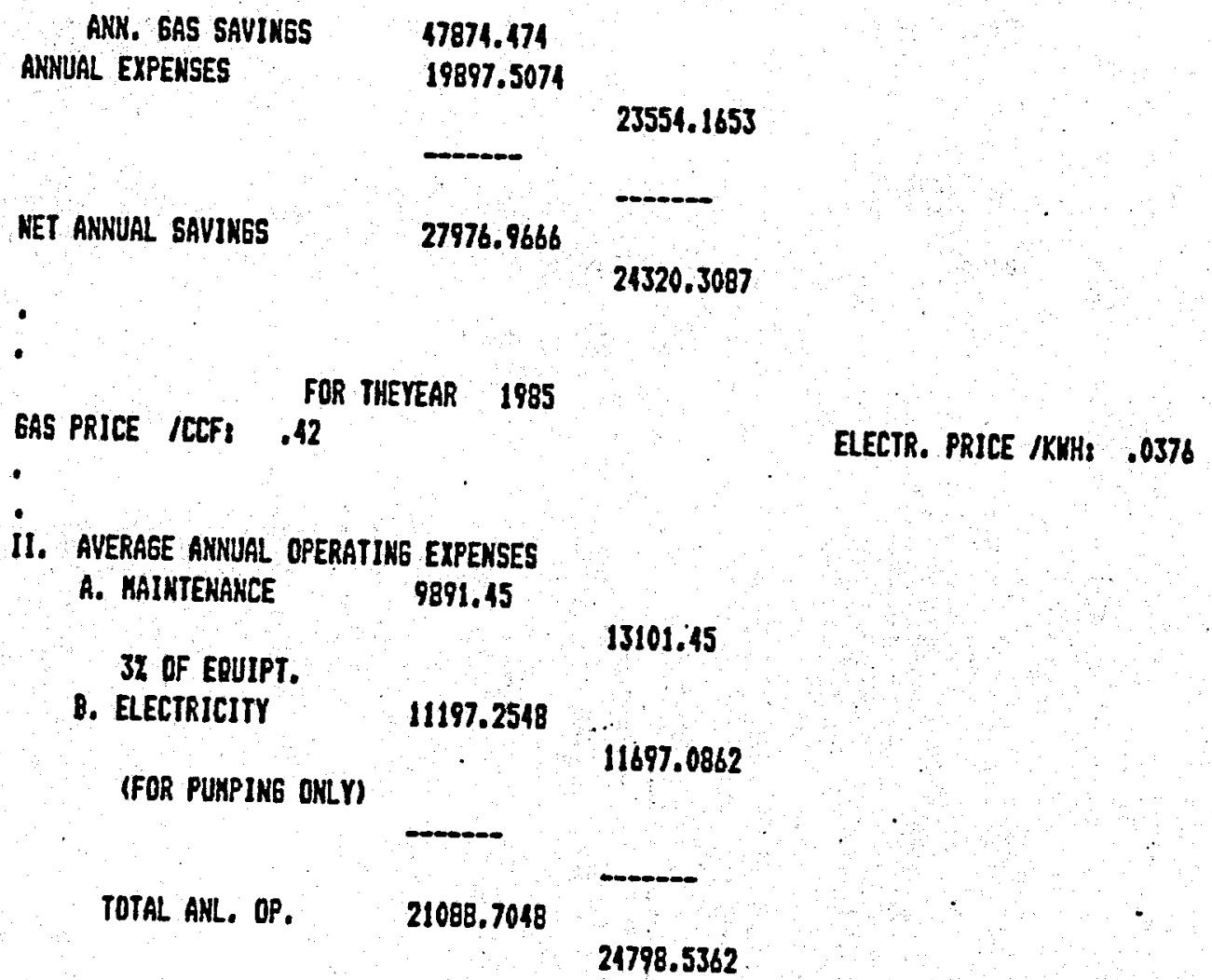

ANM. GAS SAVIHES ANWUAL EXPENSES 76745.34 21088.7048

24798.5362

NET ANMUAL SAUTHES

55656.6352

51946.8038

-

GAS PRICE ICCFI . FAS THEYEAR 1990

-

11. AVERAGE ANNUAL OPERATING EXPENSES

A. MAINTENANCE

9891.45

31 DF EQUIPT.

13101.45

B. ELECTRICITY

12418.232

(FOR PUNPING OHLY)

12972.5663

TOTAL ANL. OP.

22309.682

26074.0163

ELECTR, PRICE /KNHs .0417 
NET ANNUAL INCOME

ANN. GAS SAVINGS

01313.515

ANHUAL EXPEXSES

26074.0163

NET AKMUAL SAVINGS

59003.853

55239.4987

-

GAS PRICE TCCF: $\$ 06$

FOR THEYEAR 1995 .

11. AVERABE AHWUAL OPERATING EXPENSES

A. MAINTENAKCE

9891.45

3\% OF EQUIPT.

1. ELECTRICITI

12716.0313

(FOR PUKATAG ONLY)

13101.45

ELECTR, PRICE NKWH 0427

13283.6591

TOTAL AML. OP.

22607.4813

26385.1091

NET ANNUAL INCOME

- and. gas savings

ANKUAL EXPENSES

92459.862

22607.4813

26385.1091

-

NET ANMUAL SAVTHES

69852.3807

.66074 .7529

FOR THEYEAR 2000

GAS PRICE RCCF: .506

II. AVERAGE ANMUAL OPERATHNG EXPENSES

A. MAIUTENANCE

9891.45

37 of EPIIPT.

*. BECTRICITY

12984.0507

(FOR PUAPING GNLY)

TETAL ARL. OP.

22875.5007

26665.0925

NET ANNUAL INCOME

$\because$

ANN. GAS SAVINGS

AMNUAL EXPENSES

92459.862

22875.5007

26665.0925

AET ANHUAL SAVINGS

69584.3612
13101.45

13563.6425

EIECTR. PRICE IKNH: .0436 


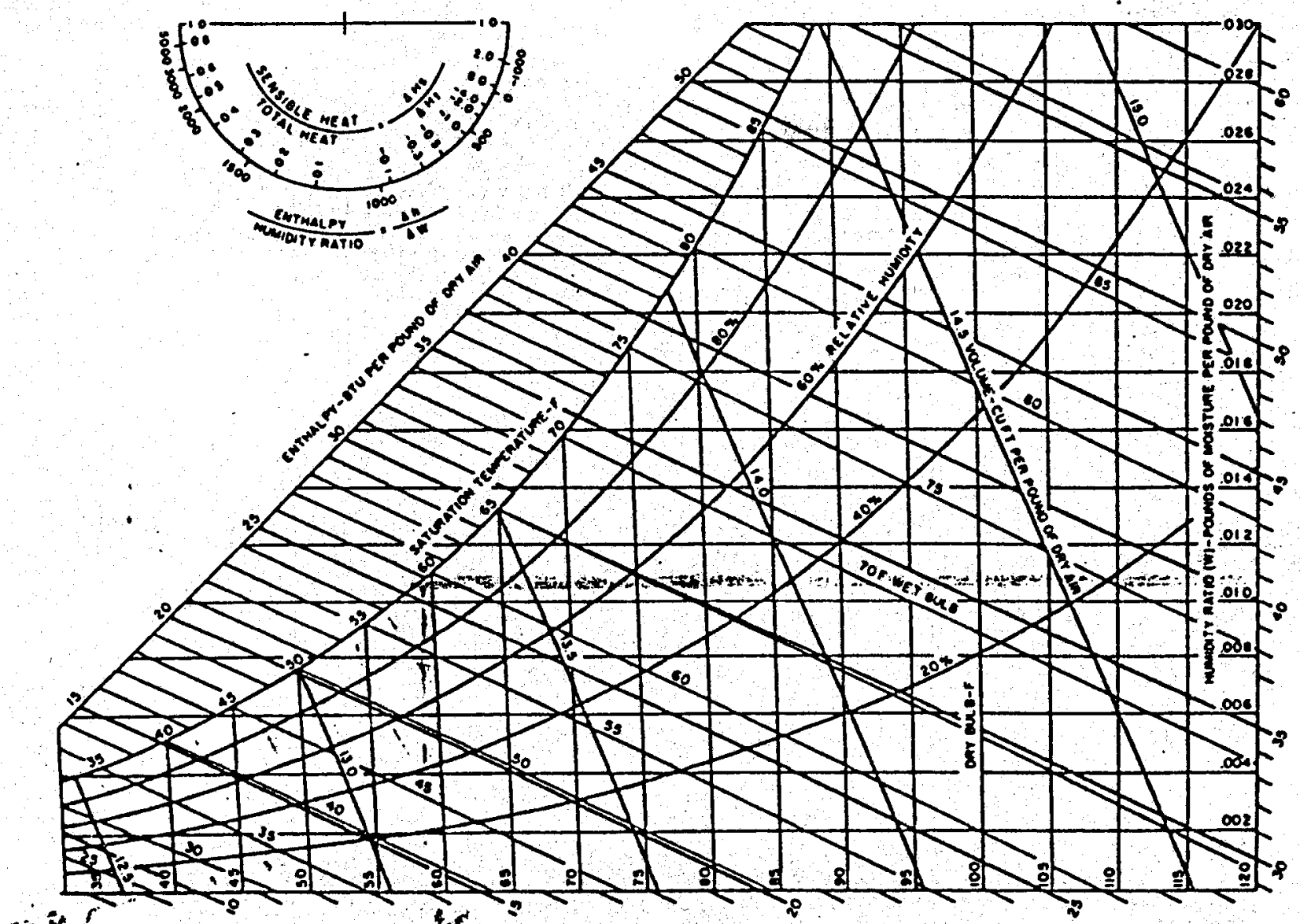

. Fon abridgment or Chart 1

An additional and larger portion of the error, arising from the mixing entropy, can be expressed as a correction term:

$$
\begin{aligned}
s= & 0.1579\left[\left(1+1.6078 \mu W_{s}\right) \times \log _{10}\right. \\
& \times\left(1+1.6078_{\mu} W_{s}-1.607 \psi_{\mu} W_{s} \log _{10}(\mu)\right. \\
& \left.-\mu\left(1+1.6078 W_{s}\right) \log _{10}\left(1+1.6078 W_{s}\right)\right]
\end{aligned}
$$

Table 3 shows values of cocfficients $A, B$, and $C$ in $E q 40$. 42, and 44 , respectively, and maximum values of correction terms is $h \mathrm{~s}$.

\section{PSYCHROMETRIC CHARTS}

A psychrometric chart is a graphical representation of the thermodynamic properties of moist air. Its distinctive features are of practical value in solving engineering problems.

The choice of coordinates for a psychrometric chart is arbitrary. Mollier 14 was the first to use coordinates of enthalpy and humidity ratio. An $h, W$ chast provides convenient graphical solutions of many moist air problems with a minimum of thermodynamic approximations. ASHRAE has developed five Mollier-type psychrometric charts.

Charts 1, 2, and 3 are for sea level pressure. Chart 4 is for s000-ft altitude (24.89 in. H8) $_{8}$. Chast 5 is for 7500 -ft altitude (22.65 in. $\mathrm{H}_{8}$ ). All charts use oblique-angle coordinates of enthalpy and humidity ratio, and are consistent with the data of Table 1, Chapter 6 and the properties computation methods of Goff and Gratch. ${ }^{2.3}$ Geometry of chart construction applying specifically to Charts 1 and 4 is a matter of record. 15

Fig. 1, abridgement of Chart 1, shows various properties represented on all charts. These include coordinates enthalpy and humidity ratio, and lines of constant dry-bulb and thermodynamic wet-bulb temperature, relative humidity, and volume.

The dry-bulb temperature ranges covered by the charts ase:

$\begin{array}{llr}\text { Charts 1,4,5 } & \text { Normal Temperature } & 3210120 \mathrm{~F} \\ \text { Chart 2 } & \text { Low Temperature } & -401050 \mathrm{~F} \\ \text { Chart } 3 & \text { High Temperature } & 6010250 \mathrm{~F}\end{array}$

Charts 1 and 4 are constructed on the identical system of coordinates. Psychrometric properties or charts for barometric pressures other than 29.921 and 24.89 in. $\mathrm{H}_{\mathrm{g}}$ may be derived by interpolation. Sufficiently exact values for most purposes may be derived by methods described earlier (see Perfect Gas Relations). The construction of charts for altitude conditions has been treated in Ref 16 through 18.

Comparison of Charts 1 and 4 by overlay reveals:

1. The dry-bulb lines coincide.

2. Wet-bulb line for a tiven temperature originate at the intersections of the corresponding dry-bulb line and the two saturation curves, and they have the same slope.

3. Humidity ratio and enthalpy for a given dry- and wet-bulb increase with altitude, but there is little change in relative humidity.

4. Volume changes rapidly; for a given dry-bulb and humidity ratio, it is practically inversely proportional to basometric pressure.

The following table compares properties from the sea level (Chart 1) and 5000-ft (Chart 4) charts:

\begin{tabular}{rllllllll}
\hline Chart No. & DB & WB & $h$ & & $W$ & rh & \\
\hline 1 & & 100 & 81 & 44.6 & 0.0186 & 45 & 14.5 \\
4 & 100 & 81 & 49.8 & 0.0234 & 46 & 17.6 \\
\hline
\end{tabular}


Nationai wealmen senvice or

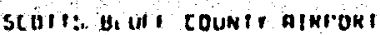

MONTHLY SUMMARY

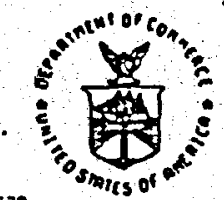

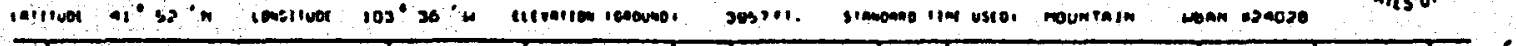

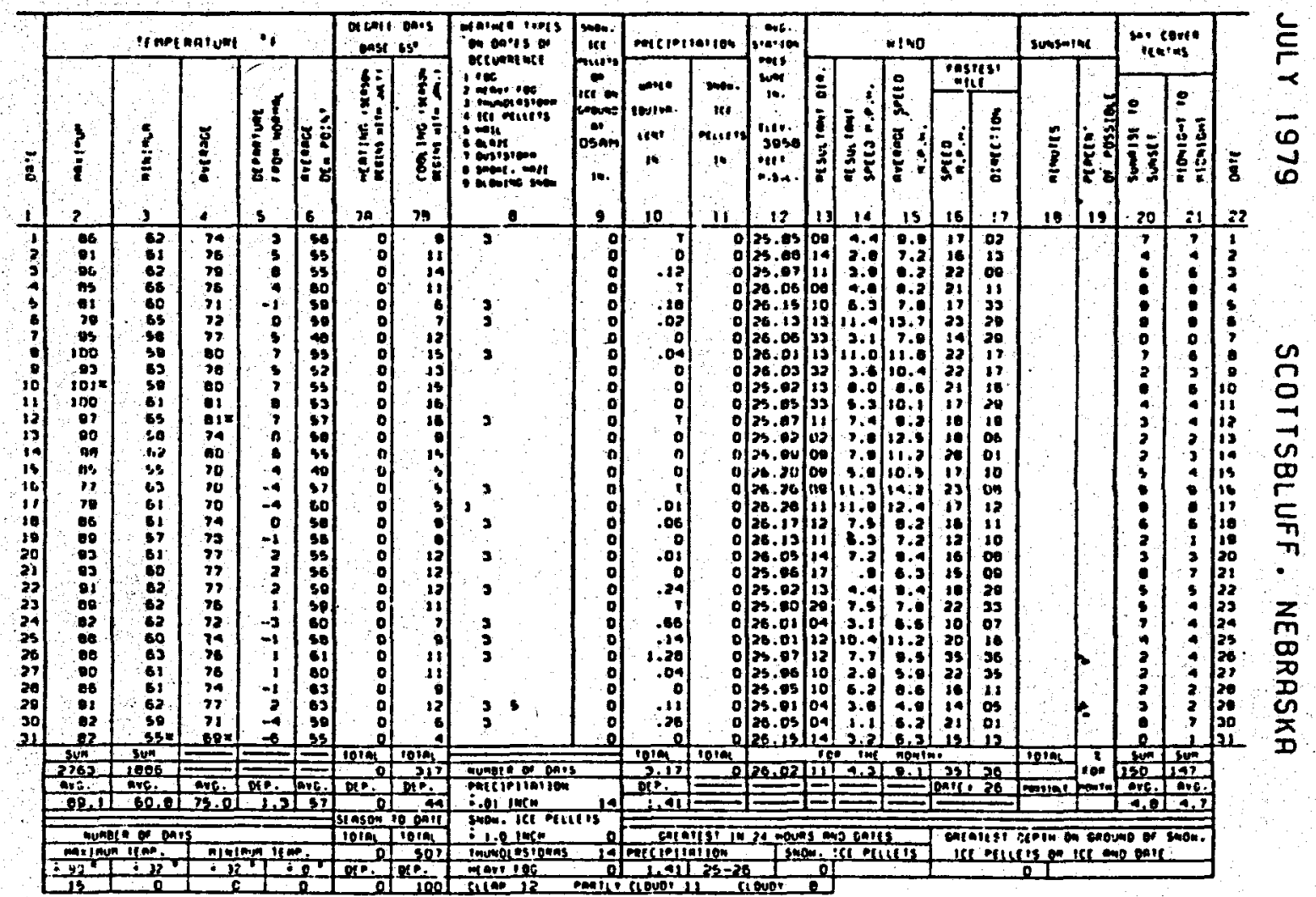

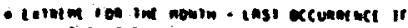
I teace tman ant

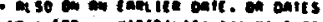

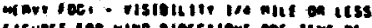

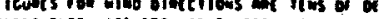

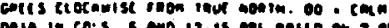

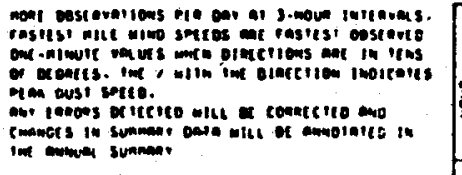

MARY BT MOURS

co.ecs mesurant

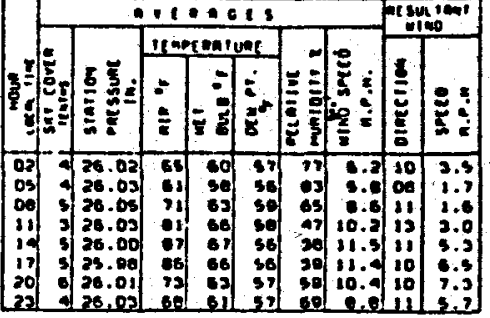

MOURIT PAECIPITATION IHATEA EOUIVALENT IN INCHESI

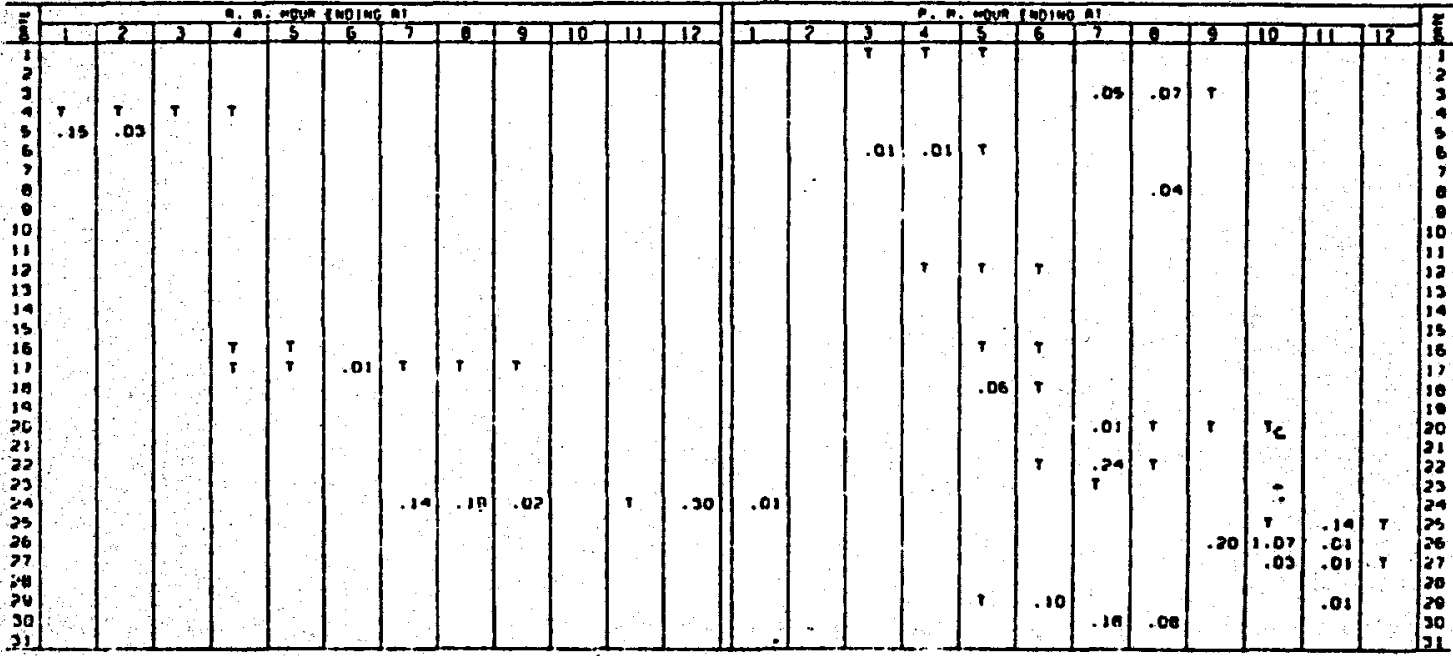

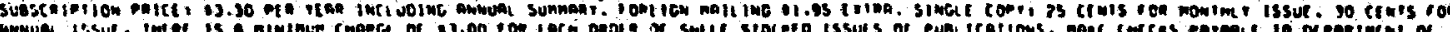

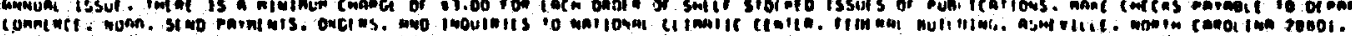

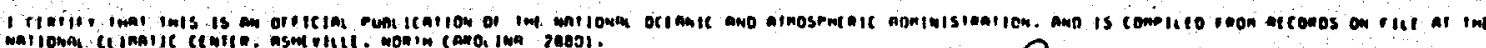

noaa

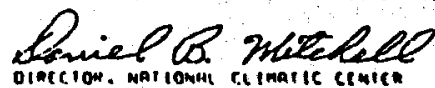
olaction. mat tomul ritmatle cinich 


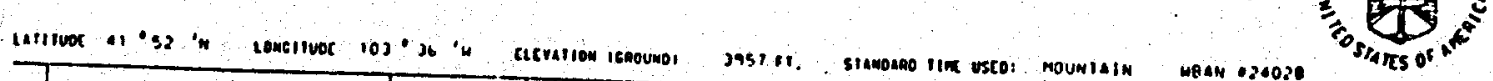

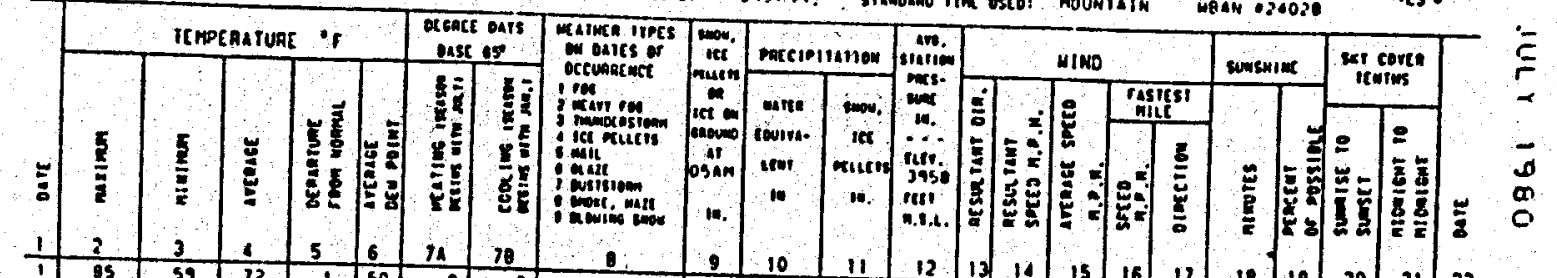

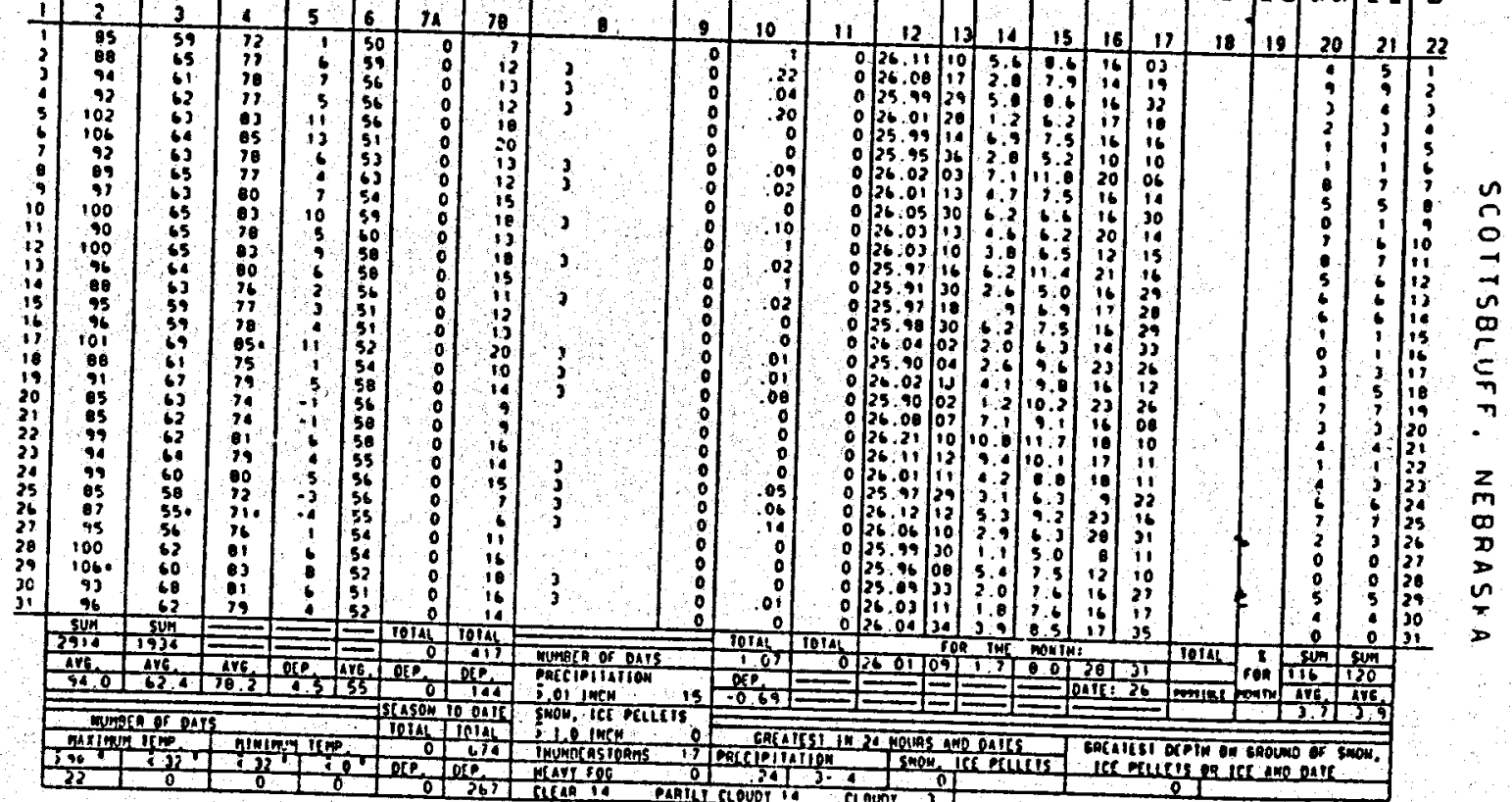

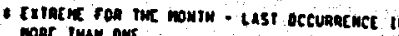
1 gacer amoung

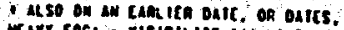

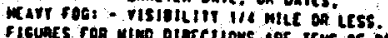

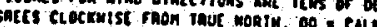

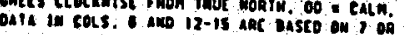

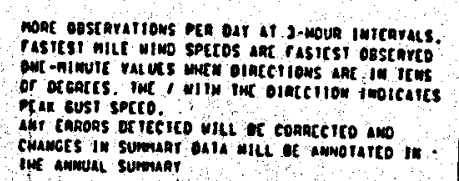

SURMARY BY HOURS

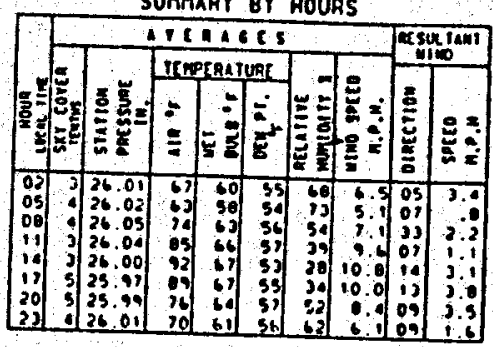

HOURLY PRECIPITATION. IHATER EQUIVALENT IN INCHESI

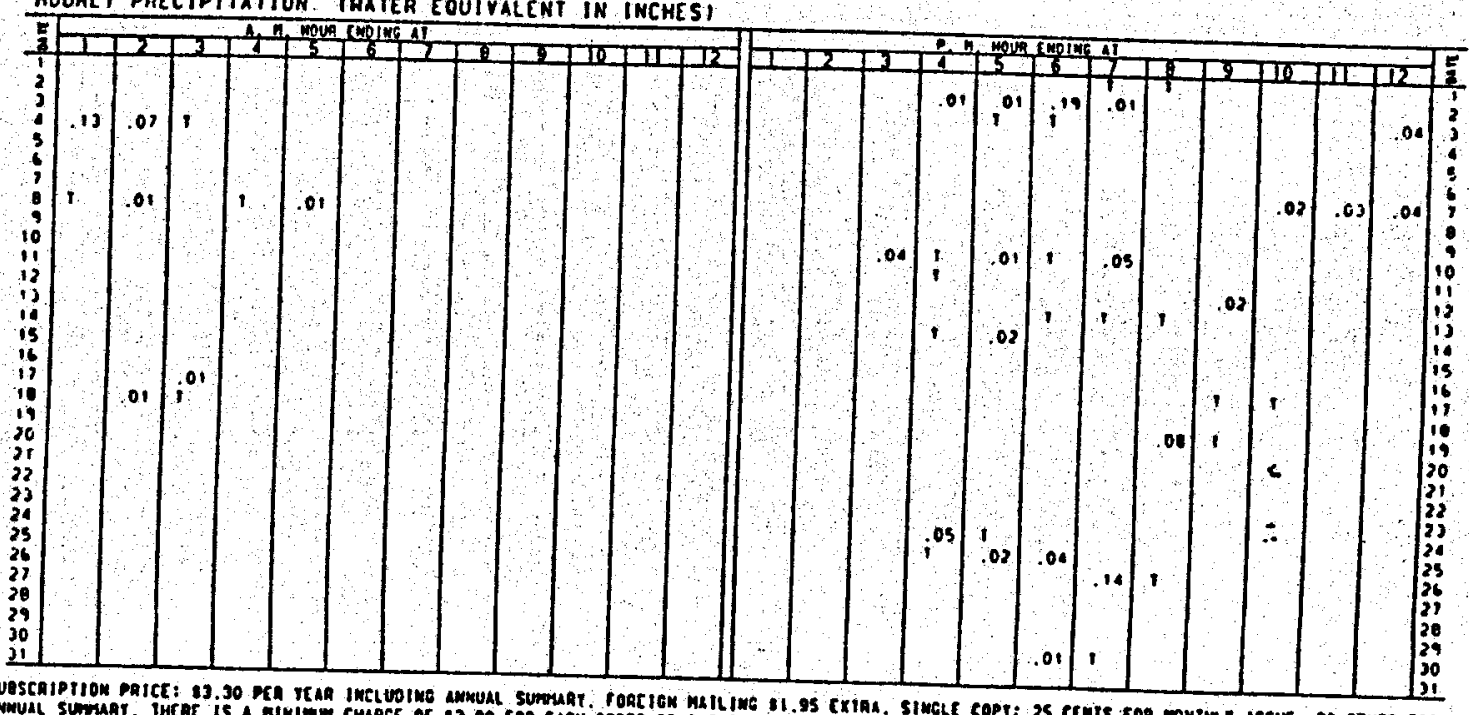

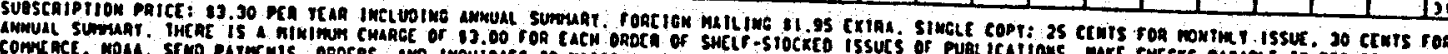

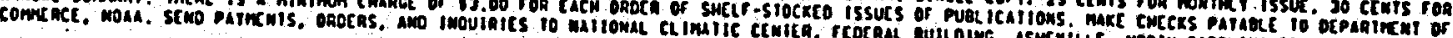
I cenuir imat this is an osficil puate 
SCOIISBLUF, NEBRASKA NATIONA WE ATER stivice OHC

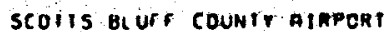

Local Climatological Data

MONTHLY SUMMARY

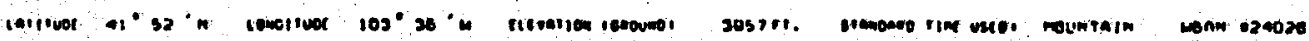

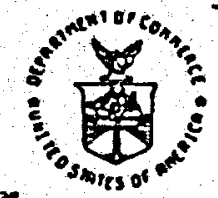

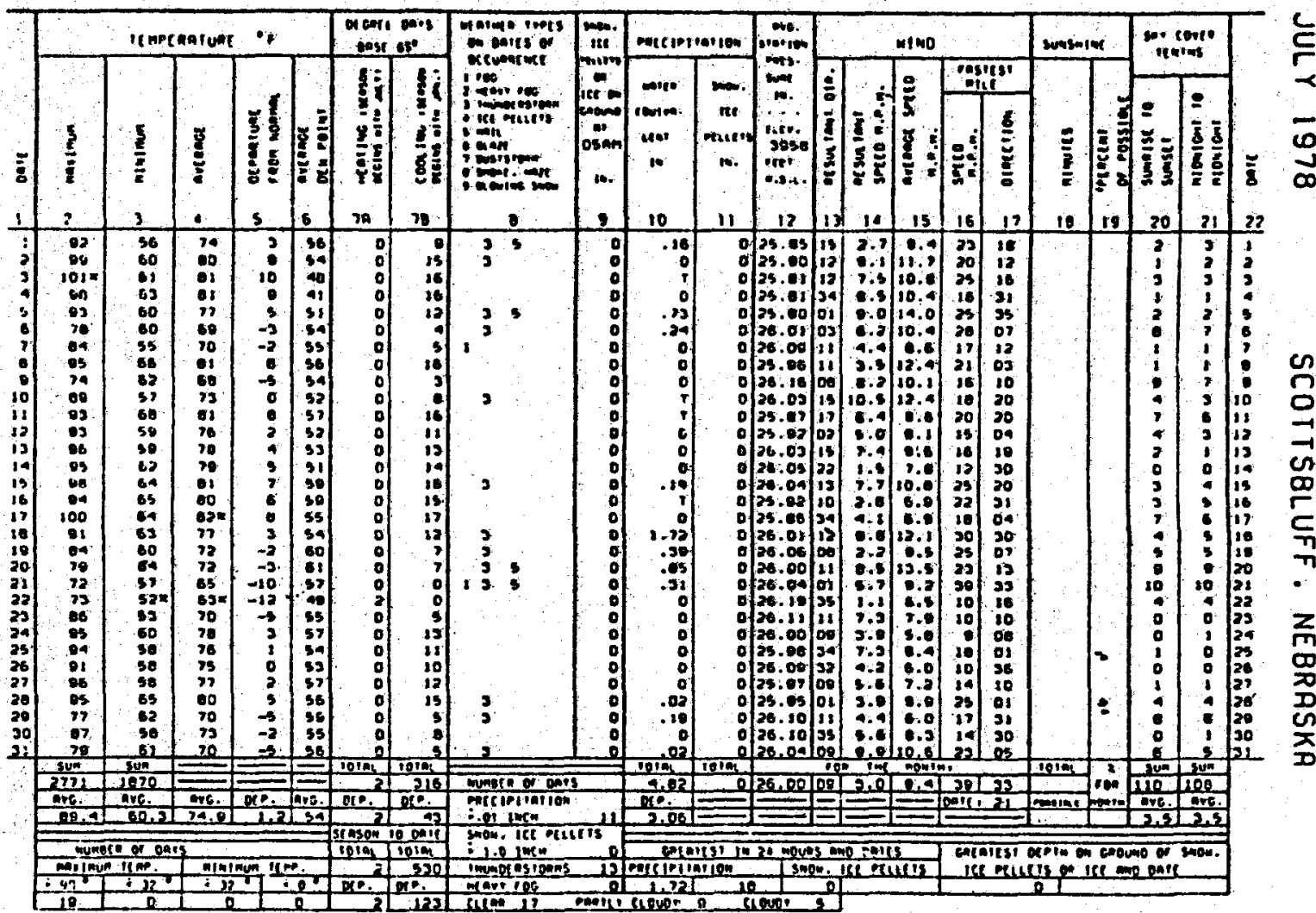

- Irietme eon tue momin - insi occunacest is

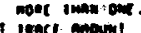

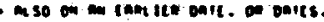

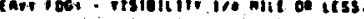

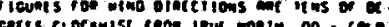

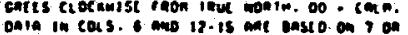

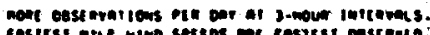

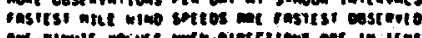

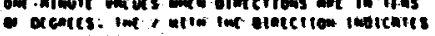
mian cost sitio.

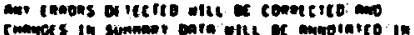
im anmivi sumpars

SUMHARY BT HOURS

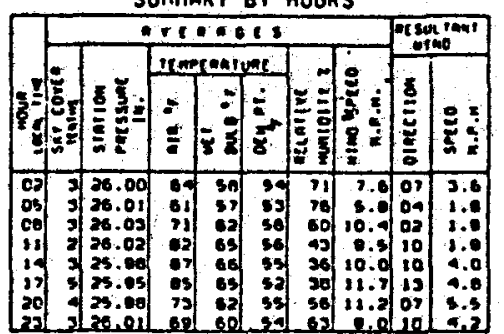

HOURIY PRECIPIIAIION IHAIER EOUIVALENI IN INCHES I

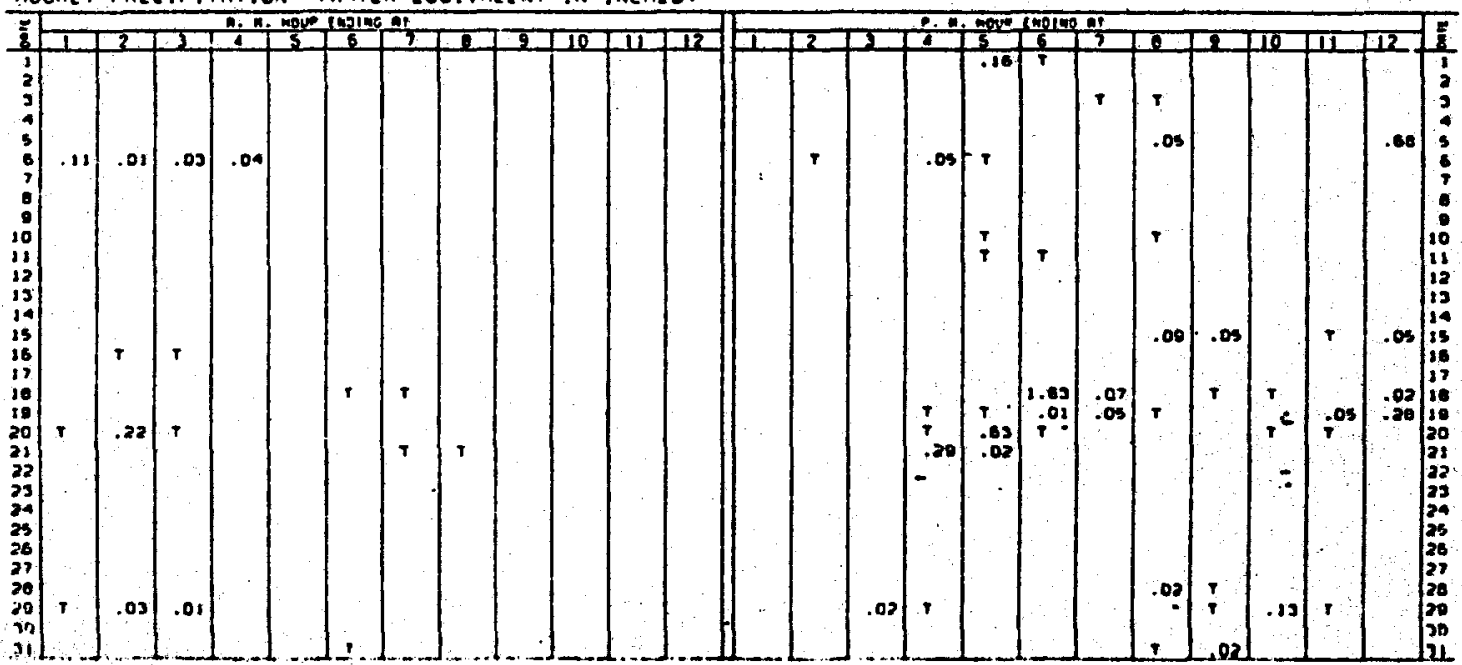

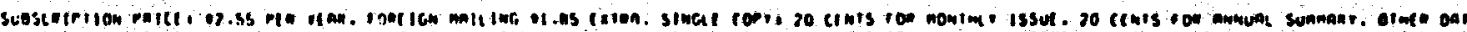

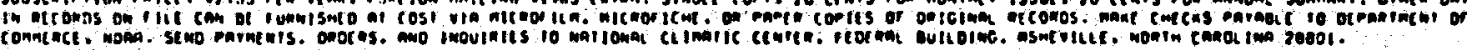

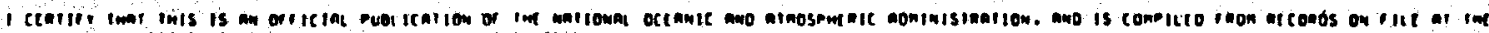

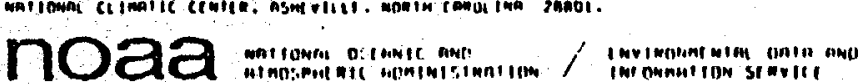

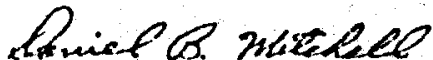

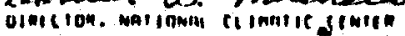


IX. References

\section{A. Geology References}

De Graw, H.M., 1969,Potentionetric surfácelfor water in the upper Dakota sands (based on calculations from arill stem tests on oil wells). Unpublished manuscript map, Nebraska Conservation and Survey Division.

Carlson, M.P. and Reed, E.C., 1961, structure Contour Map of Nebraska. Unpublished blue-Iine map, Nebraska Conservation and Survey Division.

Reed, E.C., 1952, North-South electric log correlation table, Cretaceous and Jurassic Systems, Western Nebraska. Unpublished blue-line cross section, Nebraska Conservation and Survey Division.

Schoon, R.A., 1971, Geology and Hydrology of the Dakota Formation in South Dakota. South Dakota Geological Survey Report of Investigations No. $104,55 \mathrm{p}$.

Bouwer, H., 1978, Groundwater Hydrology. McGraw Hill Co., 480p.

Volk, R.W., 1972, The Denver Basin and the Las Animas Arch. in Geologic Atlas of the Rocky Mountain Region. Rocky Mountain Association Geol. Denver, P. 281-282.

MCGookey, D.P. and others, 1972, Cretaceous system. in Geologic Atlas of the Rocky Nountain region. Rocky Mountain Assoc. Geol. Denver, P. 190-228.

Gosnold, W.D.Jr, and Eversoll, D.A., in press, usefulness of heat flow data in regional assessment of low temperature geothermal resources with special reference to Nebraska. Geothermal Resources council Transactions, v. 5 .

Gosnold, W.D.Jr. Eversoll, D.A., and Carlson, M.P., in press, Geothermal investigations in Nebraska: Methods and results. U.S. Department of Energy State Coupled Geothermal Resource Assessment Meeting, Glendwood Springs, Co, May 4-6, 1981 , Proceedings.

Freethey, G.W., 1973, Configuration of the Water Table, 1971 Scottsbluff and Chryenne Quadrangles, Nebraska. Unpublished blue-line map, Nebraska Conservation and Survey Division. 
1) "ASHRAE HANDBOOK AND PRODUCT DIRECTORY - 1976 SYSTEMS" American Society of Heating, Refrigerating and $A i r$ Conditioning Engineers, New York, 1976.

2) "ASHRAE STANDARD 90-80 Building Energy Performance Standards" ASHRAE, New York, 1980.

3) "ASHRAE HANDBOOK AND PRODUCT DIRECTORY, 1977 FUNDAMENTALS" ASHRAE, New York, 1977.

4) "The Richardson Rapia Construction Cost Estimating System" 1980, Richardson Engineering Services Inc. Solana Beach, Ca. 